\title{
Effect of the Intensity of Weed Harrowing with Spike-Tooth Harrow in Barley-Pea Mixture on Yield and Mycobiota of Harvested Grains
}

\author{
Rafał Ogórek ${ }^{1, *}$, Agnieszka Lejman ${ }^{2}$ and Piotr Sobkowicz ${ }^{2}$ (D) \\ 1 Department of Genetics, Institute of Genetics and Microbiology, University of Wroclaw, Przybyszewskiego \\ Street 63/77, 51-148 Wroclaw, Poland \\ 2 Institute of Agroecology and Plant Production, Wrocław University of Environmental and Life Sciences, \\ Grunwaldzki Sq. 24A, 53-363 Wrocław, Poland; agnieszka.lejman@upwr.edu.pl (A.L.); \\ piotr.sobkowicz@upwr.edu.pl (P.S.) \\ * Correspondence: rafal.ogorek@uwr.edu.pl; Tel.: +48-71-375-6291; Fax: +48-71-325-2151
}

Received: 30 January 2019; Accepted: 21 February 2019; Published: 21 February 2019

\begin{abstract}
Harrowing is one of the most popular mechanical methods to control weeds. Nevertheless, the relationship between the effect of different harrowing intensities using spike-tooth harrow in barley-pea intercrop on the yield and mycoflora of grains has not yet been studied. Therefore, the aim of this study was to assess the effect of harrow intensity using spike-tooth harrow in barley-pea mixture on the mycological quality of harvested grains, grain yield, as well as influence of barley and pea grain moisture on the abundance of fungi. The field experiment was carried out during 2010-2012, and it was conducted using a randomized complete block design with four replicates. Weed control was mechanical and chemical. In this study, we have shown that harrowing in barley-pea intercrops does not reduce the yield of either mixture components, both with respect to grain quantity or mycological quality after harvest, compared to controls-without harrowing and the herbicide MCPA (2-methyl-4-chlorophenoxyacetic acid). However, increasing the intensity of harrowing did not result in a consistently larger crop yield or reduction in fungal abundance in the grains. The grains' internal structures and surface of both tested components of the mixture were colonized to a large extent by cosmopolitan fungi, of which Alternaria alternata (Fr.) Keissl. was the most abundant.
\end{abstract}

Keywords: barley-pea mixture; spike-tooth harrow; yield; fungi

\section{Introduction}

At the moment, opposite agricultural trends are being observed in the world. On the one hand, developing countries, especially those in tropical regions, are constantly increasing the use of pesticides in the agricultural sector, to become self-sufficient and exist in the global economy [1]. On the other hand, many developed countries, especially those belonging to the European Union, contribute to reducing agrochemicals in agriculture and want to use integrated pest management techniques that minimize pesticide use [2,3].

The undeniable fact is that pesticides can enhance the efficiency of agricultural production. However, most of compounds carry a risk to people, other forms of life, and the surrounding environment [4]. Therefore, it is not surprising that people living in developing countries are particularly exposed to the negative effects of some pesticides [5]. The importance of this problem is reflected by the fact that pesticides contribute to death or cause chronic diseases in $\sim 1$ million people in the world every year [6]. However, it should be recognized that the toxicity of these compounds is different. For example, 2-Methyl-4-chlorophenoxyacetic acid (MCPA) is a chlorophenoxy herbicide which rarely causes death in humans. Nevertheless, acute MCPA poisoning in humans can cause 
many ailments, including those associated with liver, kidneys, digestive system as well as headache, dizziness, muscle fasciculation, hypotension, dyspnea and coma [7]. Therefore, the entire agricultural industry around the world should pay attention to excessive pesticide use in agriculture.

The agricultural industry can employ many alternative methods to reduce the use of pesticides in plant protection. One of which is the cultivation of plant species, including those genetically modified, that are resistant to selected phytopathogens and entomopathogens $[8,9]$. Another alternative way could be the use of mixed sowing instead of pure stands, or introducing appropriate mechanical treatments into agrotechnics [10,11]. In particular, the above two methods are useful for countries where the cultivation of genetically modified crops is forbidden, for organic farming, and for sustainable agricultural production.

Overall, crop mixtures, especially those in which the main components are cereals and legumes, are more resistant to stress factors such as fungal pathogens or insect pests [2,3,12]. Therefore, their yield is higher and more stable than pure stands of their component species [13]. Cereal-legume mixtures seem to be desirable for conventional agricultural production as well as for organic and sustainable farming [11]. Nevertheless, after harvest, cereals and legumes grains are colonized by a wide range of microscopic fungi, including both toxigenic and pathogenic species. The presence of these species leads to quantitative and qualitative crop losses, and thus raises concerns about the grains' wholesomeness and commercial value [2,3]. The abundance and species composition of fungi colonizing plant grains largely depend on environmental factors and morphological traits of plant [14]. Nevertheless, moisture content in the biological material is the main factor affecting fungi occurrence on plants [15].

Nowadays non-chemical methods are used to reduce the risk of yield losses not only due to weeds, but also pests, soil-borne plant pathogens, etc. through the use of appropriate treatments as well as crop rotation $[10,16,17]$. One of the mechanical weed control methods is harrowing, which is particularly effective against small seedlings of annual weeds $[16,18]$. The great advantage of this method is that it reduces both intra- and inter-row weeds, in addition to the fact that crop plants are largely resistant to uprooting after their emergence [19]. By contrast, harrowing is not very effective, it could even be considered ineffective, against perennial and firmly anchored weeds with deep roots [18]. The influence of harrowing on weed infestation of various crops has been studied, as well as the factors influencing the effectiveness of harrowing in reducing weed infestation $[13,16,20,21]$. Nevertheless, there are few reports on the effect of harrowing on grain colonization of barley-pea mixture components by microscopic fungi [2,3]. The authors of these studies show that using a spring-tine harrow can positively affect the mycological quality of the grains of both plant species. However, there are no reports on the effect of the different harrowing intensities using spike-tooth harrow on the yield and mycobiota of barley-pea mixture grains.

Therefore, the main goal of our research was to assess the effect of harrowing intensity using spike-tooth harrow in barley-pea mixture on the grains' mycological quality by determining the number and species composition of cultivable microscopic fungi after harvest. We also investigated: (1) whether harrowing and its intensity affect grain yield in barley and pea, and (2) the influence of barley and pea grains' moisture on the abundance of fungi.

\section{Materials and Methods}

\subsection{Field Experiment}

The current study was conducted on the fields of the Swojec Agricultural Experimental Station in Wrocław, Poland $\left(51^{\circ} 6^{\prime} \mathrm{N}, 17^{\circ} 8^{\prime} \mathrm{E}\right)$. One-factor field experiment was conducted over three years (2010-2012) using a randomized complete block design with four replicates. In total, 28 plots (36 $\mathrm{m}^{2}$ each) sown with a mixture of spring barley (99 germinating grains per $\mathrm{m}^{2}$ ) var. Nagradowicki; and pea (63 germinating grains per $\mathrm{m}^{2}$ ), var. Milwa, were seeded on alluvial loamy sand soil. 
The preceding crops were winter rye (2010) and winter triticale (2011, 2012). The following agronomical operations were carried out on the experimental field area: harvest of previous crop, disking, harrowing with heavy harrow, and autumn plowing to a depth of $27-29 \mathrm{~cm}$. In spring, the field was harrowed and then fertilized with superphosphate $40 \%$ (40 kg per ha), potassium salt ( $50 \mathrm{~kg}$ per ha), and ammonium nitrate 32\% (40 kg per ha). Fertilizers were incorporated into the soil using combined tillage implementation. Seeds (pea and spring barley) were seeded on 7 April 2010, 1 April 2011, and 28 April 2012. Harrowing of barley using a spike-tooth harrow was done on 8 May 2010, 28 April 2011, and 30 April 2012; at the beginning of tillering stage. The second harrowing, at the full tillering stage of barley, was carried out on 25 May 2010, 6 May 2011, and 8 May 2012. Herbicide treatment (Chwastox Extra 340SL "MCPA" with 2-methyl-4-chlorophenoxyacetic acid-1.5 L per ha) was used on 26 May 2010, 10 May 2011 and 2012. The crop was harvested on 12 August 2010, 6 August 2011, and 1 August 2012 with a combine plot harvester. The experimental design consisted of:

1. Control (without harrowing or herbicide application);

2. HT (herbicide application, Chwastox Extra 300 SL $1.5 \mathrm{~L}$ per ha at the full tillering stage of barley 23-26; the growth stage of barley according to Biologische Bundesanstalt, Bundessortenamt und Chemische Industrie "BBCH" scale);

3. Z-1-0 (one pass of spike-tooth harrow at the beginning of the barley tillering stage; $\mathrm{BBCH} 21$ );

4. Z-0-1 (one pass of spike-tooth harrow at full tillering stage of barley; $\mathrm{BBCH} 23-26$ );

5. Z-1-1 (one pass of spike-tooth harrow at the beginning of barley tillering stage and one pass at full tillering stage of barley; $\mathrm{BBCH} 21+23-26)$;

6. Z-2-1 (two passes of spike-tooth harrow at the beginning of the barley tillering stage and one pass at full tillering stage of barley; $\mathrm{BBCH} 21+23-26)$;

7. Z-2-2 (two passes of spike-tooth harrow at the beginning of the barley tillering stage and two passes at full tillering stage of barley; $\mathrm{BBCH} 21+23-26)$.

Results on the effect of harrowing on the density of mono- and dicotyledonous weeds have been presented elsewhere [22].

\subsection{Assessment of the Yield of Pea and Barley}

At the mixture's full maturity, four consecutive rows of each species with a length of $1 \mathrm{~m}$ were collected $\left(0.5 \mathrm{~m}^{2}\right)$. The yields were weighed using a laboratory scale (Radwag WPE 300, accuracy: $\pm 0.01 \mathrm{~g}$; Radwag, Radom, Poland). The harvest index was then calculated based on grain and straw yield according to Wnuk et al. [23].

\subsection{Measurement of Pea and Spring Barley Grains Moisture}

Grain moisture of both species was measured on the day of mycological analysis using a moisture analyzer (Radwag WPS 210S, accuracy: $\pm 0.01 \%$; Radwag, Radom, Poland). Humidity values are given as $\%$ of the water evaporated in the sample.

\subsection{Mycological Assessment of Pea and Barley Grains}

Eight hundred grains were chosen at random from each experimental treatment in each year of the study. One hundred grains were surface disinfected (pea in $0.5 \% \mathrm{NaOCl}$ for $1 \mathrm{~min}$, and barley in $1.0 \% \mathrm{NaOCl}$ for $10 \mathrm{~min}$ ) before transferring into PDA medium (Potato Dextrose Agar, Biocorp) in Petri dishes. Another 100 grains were placed on PDA without surface disinfection. Grains were incubated in four replicates at $22 \pm 1.0^{\circ} \mathrm{C}$ for 5-14 days in the dark. The CFU (Colony Forming Unit) number per 100 grains was then calculated and fungi were identified. Generally, fungal structures were observed on PDA, and in the case of Penicillium, on Malt Extract Agar (MEA, Biocorp), Czapek-Dox Agar (1.2\% agar, Biocorp), and Czapek Yeast Autolysate Agar (CYA). Fungi were then identified using taxonomic literature [24-26]. The phenotypes of some fungi were also compared with the strains from R. Ogorek's collection (Department of Genetics, Institute of Genetics and Microbiology, University of Wrocław, 
Wrocław, Poland), which were identified using phenotypic and molecular studies, and their internal transcribed spacer sequences were identified by the National Center for Biotechnology Information (Bethesda, Rockville, MD, USA).

\subsection{Data Analyses}

The data were subjected to statistical analysis using the Statistica 12.0 package (StatSoft Polska Sp. z o.o., Kraków, Poland). For this purpose, we used one-way analysis of variance (ANOVA) and the Tukey HSD (honest significant difference) test at $\alpha \leq 0.05$ for fungal colonization tests, yield of grains, and grain moisture. Prior to ANOVA, the percentage data of grain moisture were transformed to Bliss [27] angular degrees by applying the formula $y=\arcsin (\text { value } \%)^{-0.5}$. After transformation, the variance was approximately constant, allowing ANOVA to compare particular components [27]. The Pearson ( $r$ ) correlation coefficient at $\alpha \leq 0.05$ was used to determine the relation between harrowing intensity of spike-tooth harrow in the barley-pea mixture, yield and moisture of pea and barley grains, and the abundance of fungi. The calculations were performed on the basis of means from three years (2010-2012). In the analysis, harrowing intensity was solely based on the number of harrowings, not on the timing (i.e., Z-0-1 was considered to have the same intensity as Z-1-0). Years was included as a fixed factor, and block as a random factor. Pearson's $r$ can range from +1 to -1 . A value of 0 indicates that there is no association between the two variables. A value less than 0 indicates a negative association; that is, as the value of one variable increases, the value of the other decreases. A value greater than 0 indicates a positive association; that is, as the values of both variables increase.

\section{Results}

In general, the intensity of harrowing did not significantly affect the average grain yield and the harvest index of both tested components of the mixture over the years tested. Significant differences in grain yield were recorded in 2011 for barley $\left(p_{\mathrm{HT}, \mathrm{Z}-2-1}=0.0446\right)$ and in 2012 for pea $\left(p_{\mathrm{HT}, \mathrm{Z}-1-1}=0.0079\right)$. In 2011, HT treatment yielded more barley grain than Z-2-1. While in 2012, HT treatment yielded more pea grain than any other treatment. Barley grain yield was also statistically different between the years of research for the control $\left(p_{2011}, 2012=0.0397\right)$, HT $\left(p_{2010,2011}=0.0134\right)$, and Z-1-0 $\left(p_{2010,2011}=0.0263\right)$, as well as in pea for HT $\left(p_{2011,2012}=0.0203\right)$ (Table 1).

Table 1. Grain yield of spring barley and pea $\left(\mathrm{g} \mathrm{m}^{-2}\right)$.

\begin{tabular}{|c|c|c|c|c|c|c|c|c|c|c|c|}
\hline \multirow{2}{*}{\multicolumn{2}{|c|}{ Treatment }} & \multirow{2}{*}{\multicolumn{2}{|c|}{2010}} & \multirow{2}{*}{\multicolumn{2}{|c|}{2011}} & \multirow{2}{*}{\multicolumn{2}{|c|}{2012}} & \multicolumn{4}{|c|}{ Mean for 2010-2012 } \\
\hline & & & & & & & & \multicolumn{2}{|c|}{ Yield } & \multicolumn{2}{|c|}{ Harvest Index } \\
\hline \multirow{7}{*}{$\begin{array}{l}\text { Spring } \\
\text { barley }\end{array}$} & Control & 141 & ${ }^{\mathrm{a}} \mathrm{AB}^{1}$ & 256 & ${ }_{\mathrm{A}}^{\mathrm{a}}$ & 132 & $a_{B}$ & 176.33 & a & 0.49 & a \\
\hline & $\mathrm{HT}$ & 154 & ${ }^{\mathrm{a}}$ & 322 & ${ }^{a} \mathrm{~A}$ & 241 & ${ }^{\mathrm{a}} \mathrm{AB}$ & 239.00 & a & 0.56 & a \\
\hline & Z-1-0 & 147 & $a_{B}$ & 270 & $\mathrm{ab}_{\mathrm{A}}$ & 174 & ${ }^{a} \mathrm{AB}$ & 197.00 & a & 0.52 & a \\
\hline & Z-0-1 & 179 & ${ }^{a} \mathrm{~A}$ & 226 & ${ }^{a b}{ }_{A}$ & 218 & ${ }^{\mathrm{a}} \mathrm{A}$ & 207.67 & a & 0.52 & a \\
\hline & Z-1-1 & 151 & ${ }^{a} \mathrm{~A}$ & 268 & ${ }^{a b}{ }_{A}$ & 213 & ${ }^{\mathrm{a}} \mathrm{A}$ & 210.67 & $\mathrm{a}$ & 0.52 & a \\
\hline & $\mathrm{Z}-2-1$ & 160 & ${ }^{a} \mathrm{~A}$ & 184 & $\mathrm{~b}_{\mathrm{A}}$ & 212 & ${ }^{\mathrm{a}} \mathrm{A}$ & 185.33 & $\mathrm{a}$ & 0.51 & a \\
\hline & Z-2-2 & 167 & ${ }^{\mathrm{a}} \mathrm{A}$ & 213 & ${ }^{a b} \mathrm{~A}$ & 213 & ${ }^{\mathrm{a}} \mathrm{A}$ & 197.67 & a & 0.52 & a \\
\hline \multirow{7}{*}{ Pea } & Control & 111 & ${ }^{a}{ }_{A}$ & 102 & ${ }^{a} \mathrm{~A}$ & 89 & $\mathrm{~b}_{\mathrm{A}}$ & 100.67 & $\mathrm{a}$ & 0.47 & $\mathrm{a}$ \\
\hline & HT & 89 & $a_{B}$ & 112 & $a_{B}$ & 216 & $\mathrm{a}_{\mathrm{A}}$ & 139.00 & a & 0.47 & a \\
\hline & Z-1-0 & 101 & ${ }^{a} \mathrm{~A}$ & 86 & ${ }^{a} \mathrm{~A}$ & 93 & $\mathrm{~b}_{\mathrm{A}}$ & 93.33 & $\mathrm{a}$ & 0.47 & a \\
\hline & Z-0-1 & 72 & ${ }^{a} \mathrm{~A}$ & 104 & ${ }^{a} \mathrm{~A}$ & 92 & $\mathrm{~b}_{\mathrm{A}}$ & 89.33 & $\mathrm{a}$ & 0.47 & a \\
\hline & Z-1-1 & 70 & ${ }^{a} \mathrm{~A}$ & 78 & ${ }^{a} \mathrm{~A}$ & 105 & $\mathrm{~b}_{\mathrm{A}}$ & 84.33 & $\mathrm{a}$ & 0.45 & a \\
\hline & Z-2-1 & 83 & ${ }^{a} \mathrm{~A}$ & 111 & ${ }^{\mathrm{a}} \mathrm{A}$ & 71 & $\mathrm{~b}_{\mathrm{A}}$ & 88.33 & $\mathrm{a}$ & 0.47 & a \\
\hline & Z-2-2 & 93 & ${ }^{a} \mathrm{~A}$ & 147 & ${ }^{a} \mathrm{~A}$ & 101 & $\mathrm{~b}_{\mathrm{A}}$ & 113.67 & $\mathrm{a}$ & 0.51 & $\mathrm{a}$ \\
\hline
\end{tabular}

${ }^{1}$ For each treatment, means followed by the same letter are not statistically different at $\alpha \leq 0.05$ according to Tukey's HSD test. Small letters mark treatment differences within a given year; they refer to column means. Capital letters mark the effect of years on grain moisture within a given treatment; they refer to row means. 
Spring barley and pea grain moisture before mycological analysis did not differ statistically within each year of the study and when averaged over years (Table 2). However, there were significant differences between the research years for some treatments. Such differences were noted in barley for treatments such as control $\left(p_{2011}, 2012=0.0064\right), Z-1-0\left(p_{2011,2012}=0.0081\right), Z-0-1\left(p_{2011,2010}=0.0042\right.$, $\left.p_{2010,2012}=0.0056\right) ;$ and in pea for control $\left(p_{2011,2012}=0.0076\right)$, HT $\left(p_{2010,2011}=0.0029\right)$, and Z-2-1 $\left(p_{2010,2011}=0.0034\right)$.

Table 2. The average moisture of spring barley and pea grains (\%).

\begin{tabular}{|c|c|c|c|c|c|c|c|c|c|}
\hline \multicolumn{2}{|c|}{ Treatment } & \multicolumn{2}{|c|}{2010} & \multicolumn{2}{|c|}{2011} & \multicolumn{2}{|c|}{2012} & \multicolumn{2}{|c|}{ Mean for 2010-2012 } \\
\hline \multirow{8}{*}{ Spring barley } & Control & 4.43 & ${ }^{a} \mathrm{AB}^{1}$ & 5.93 & $\mathrm{a}_{\mathrm{A}}$ & 2.34 & $a_{B}$ & 4.23 & a \\
\hline & $\mathrm{HT}$ & 4.00 & ${ }^{\mathrm{a}} \mathrm{A}$ & 5.09 & $\mathrm{a}_{\mathrm{A}}$ & 2.39 & $\mathrm{a}_{\mathrm{A}}$ & 3.83 & a \\
\hline & Z-1-0 & 5.20 & ${ }^{a} \mathrm{AB}$ & 6.89 & ${ }^{\mathrm{a}} \mathrm{A}$ & 2.75 & $\mathrm{a}_{\mathrm{B}}$ & 4.97 & a \\
\hline & Z-0-1 & 5.30 & $\mathrm{a}_{\mathrm{B}}$ & 6.47 & $\mathrm{a}_{\mathrm{A}}$ & 3.45 & ${ }^{a}{ }_{C}$ & 5.07 & a \\
\hline & Z-1-1 & 4.86 & ${ }^{\mathrm{a}} \mathrm{A}$ & 4.80 & $\mathrm{a}_{\mathrm{A}}$ & 4.12 & $\mathrm{a}_{\mathrm{A}}$ & 4.59 & a \\
\hline & Z-2-1 & 4.45 & ${ }^{a} \mathrm{~A}$ & 4.64 & $\mathrm{a}_{\mathrm{A}}$ & 3.25 & $\mathrm{a}_{\mathrm{A}}$ & 4.11 & a \\
\hline & $\mathrm{Z}-2-2$ & 4.89 & $\mathrm{a}_{\mathrm{A}}$ & 5.06 & ${ }^{\mathrm{A}} \mathrm{A}$ & 3.84 & ${ }^{\mathrm{A}}$ & 4.60 & a \\
\hline & Mean & 4.93 & $\mathrm{~A}$ & 5.89 & $\mathrm{~A}$ & 3.24 & A & \multicolumn{2}{|c|}{-} \\
\hline \multirow{8}{*}{ Pea } & Control & 6.32 & ${ }^{a}{ }_{A B}$ & 4.10 & $a_{B}$ & 8.04 & $\mathrm{a}_{\mathrm{A}}$ & 6.15 & a \\
\hline & $\mathrm{HT}$ & 7.98 & ${ }^{a} \mathrm{~A}$ & 5.27 & $a_{B}$ & 10.11 & $\mathrm{a}_{\mathrm{A}}$ & 7.79 & $\mathrm{a}$ \\
\hline & Z-1-0 & 7.80 & ${ }^{a} \mathrm{~A}$ & 7.10 & $\mathrm{a}_{\mathrm{A}}$ & 8.22 & $\mathrm{a}_{\mathrm{A}}$ & 7.71 & a \\
\hline & Z-0-1 & 7.89 & ${ }^{a} \mathrm{~A}$ & 7.37 & $\mathrm{a}_{\mathrm{A}}$ & 7.67 & $\mathrm{a}_{\mathrm{A}}$ & 7.64 & a \\
\hline & Z-1-1 & 6.56 & ${ }^{a} \mathrm{~A}$ & 5.09 & $\mathrm{a}_{\mathrm{A}}$ & 6.89 & $\mathrm{a}_{\mathrm{A}}$ & 6.18 & a \\
\hline & Z-2-1 & 6.63 & ${ }^{a} \mathrm{~A}$ & 5.28 & $a_{B}$ & 7.21 & $\mathrm{a}_{\mathrm{A}}$ & 6.37 & a \\
\hline & $\mathrm{Z}-2-2$ & 6.45 & $\mathrm{a}_{\mathrm{A}}$ & 4.99 & ${ }^{\mathrm{a}} \mathrm{A}$ & 7.09 & ${ }^{\mathrm{a}} \mathrm{A}$ & 6.18 & a \\
\hline & Mean & 7.09 & A & 5.60 & A & 7.89 & $\mathrm{~A}$ & \multicolumn{2}{|c|}{ - } \\
\hline
\end{tabular}

\footnotetext{
${ }^{1}$ For each treatment, means followed by the same letter are not statistically different at $\alpha \leq 0.05$ according to Tukey's HSD test. Small letters mark treatment differences within a given year; they refer to column means. Capital letters mark the effect of years within a given treatment; they refer to row means.
}

More colony forming units of fungi were isolated from the non-disinfected grains of both tested components of the mixture compared to the disinfected ones (Table 3). The intensity of harrowing did not significantly affect the average number of mycobiota from the three years of research, with the exception of non-disinfected pea grains $\left(p_{\mathrm{Z}-2-1, \mathrm{HT}}=0.0076\right)$. Nevertheless, research has shown statistically significant differences in the total number of fungi between treatments within a given year, and in some cases between years. However, no unambiguous tendency was noticed (Table 3). On the other hand, we detected a positive correlation between grain moisture and the number of fungi CFU isolated from disinfected and non-disinfected barley grains (respectively, $r=0.47$ and $p=0.2920$, $r=0.60$ and $p=0.1528$ ). A similar trend was observed between the grain yields and the number of fungi CFU isolated from disinfected and non-disinfected barley grains (respectively, $r=0.33$ and $p=0.4744$, $r=0.38$ and $p=0.4005)$. In contrast, correlations in the case of pea grain yield and the abundance of fungi were negative ( $r=-0.84$ and $p=0.018$ for disinfected grains, $r=-0.59$ and $p=0.1645$ for non-disinfected grains). However, most of these correlations were not statistically significant. 
Table 3. The average number of total fungi isolated from disinfected and non-disinfected spring barley and pea grains in 2010-2012 (CFU (Colony Forming Unit) per 100 grains).

\begin{tabular}{|c|c|c|c|c|c|c|c|c|c|c|}
\hline \multicolumn{3}{|c|}{ Treatment } & \multicolumn{2}{|c|}{2010} & \multicolumn{2}{|c|}{2011} & \multicolumn{2}{|c|}{2012} & \multicolumn{2}{|c|}{ Mean for 2010-2012 } \\
\hline \multirow{14}{*}{$\begin{array}{l}\text { Spring } \\
\text { barley }\end{array}$} & \multirow{7}{*}{ disinfected } & Control & 84 & $b_{B} 1$ & 82 & $\mathrm{~b}_{\mathrm{B}}$ & 99 & $\mathrm{a}_{\mathrm{A}}$ & 88.3 & $\mathrm{a}$ \\
\hline & & HT & 79 & $\mathrm{bc}_{\mathrm{B}}$ & 82 & $\mathrm{~b}_{\mathrm{B}}$ & 100 & ${ }^{\mathrm{a}} \mathrm{A}$ & 87.0 & a \\
\hline & & Z-1-0 & 82 & $\mathrm{~b}_{\mathrm{B}}$ & 69 & $\mathrm{~d}_{\mathrm{C}}$ & 100 & ${ }^{a} \mathrm{~A}$ & 83.7 & $\mathrm{a}$ \\
\hline & & Z-0-1 & 98 & $\mathrm{a}_{\mathrm{A}}^{\mathrm{D}}$ & 99 & ${ }^{a} \mathrm{~A}$ & 102 & $\mathrm{a}_{\mathrm{A}}$ & 99.7 & a \\
\hline & & Z-1-1 & 91 & $\mathrm{ab}_{\mathrm{B}}$ & 80 & ${ }^{b} \mathrm{C}$ & 102 & $\mathrm{a}_{\mathrm{A}}$ & 91.0 & a \\
\hline & & $\mathrm{Z}-2-1$ & 75 & $\mathrm{c}_{\mathrm{B}}^{\mathrm{D}}$ & 68 & $d_{B}$ & 86 & $\mathrm{c}_{\mathrm{A}}$ & 76.3 & a \\
\hline & & Z-2-2 & 79 & ${ }^{b c}{ }_{B}$ & 74 & ${ }^{\mathrm{c}}{ }_{\mathrm{C}}$ & 94 & $\mathrm{~b}_{\mathrm{A}}^{\mathrm{A}}$ & 82.3 & a \\
\hline & \multirow{7}{*}{ non-disinfected } & Control & 102 & $\mathrm{ab}_{\mathrm{B}}$ & 118 & $\mathrm{~b}_{\mathrm{A}}$ & 101 & $e_{B}$ & 107.0 & $\mathrm{a}$ \\
\hline & & HT & 100 & $\mathrm{~b}_{\mathrm{B}}$ & 113 & ${ }^{\mathrm{c}} \mathrm{A}$ & 114 & $\mathrm{abc}_{\mathrm{A}}$ & 109.0 & a \\
\hline & & $Z-1-0$ & 106 & $a_{B}$ & 114 & ${ }^{\mathrm{c}} \mathrm{A}$ & 116 & $\mathrm{ab}_{\mathrm{A}}$ & 112.0 & a \\
\hline & & Z-0-1 & 101 & $b_{B}^{D}$ & 124 & ${ }^{\mathrm{a}} \mathrm{A}$ & 106 & $\mathrm{cde}_{B}$ & 110.3 & a \\
\hline & & Z-1-1 & 100 & $b_{B}$ & 116 & $\mathrm{bc}_{\mathrm{A}}$ & 110 & $\mathrm{bcd}_{\mathrm{AB}}^{\mathrm{D}}$ & 108.7 & $\mathrm{a}$ \\
\hline & & Z-2-1 & 99 & $\mathrm{~b}_{\mathrm{A}}^{\mathrm{D}}$ & 101 & $\mathrm{e}_{\mathrm{A}}^{\mathrm{A}}$ & 103 & $\mathrm{e}_{\mathrm{A}}$ & 101.0 & a \\
\hline & & Z-2-2 & 102 & ${ }^{a b}{ }_{C}$ & 109 & $\mathrm{~d}_{B}$ & 122 & ${ }^{\mathrm{a}} \mathrm{A}$ & 111.0 & a \\
\hline \multirow{14}{*}{ Pea } & \multirow{7}{*}{ disinfected } & Control & 45 & ${ }^{c}{ }_{C}$ & 50 & $\mathrm{~b}_{\mathrm{B}}$ & 62 & ${ }^{c}{ }_{A}$ & 52.3 & $\mathrm{a}$ \\
\hline & & HT & 42 & $\mathrm{de}_{\mathrm{B}}$ & 37 & $\mathrm{~d}_{\mathrm{C}}^{\mathrm{D}}$ & 57 & $\mathrm{~d}_{\mathrm{A}}$ & 45.3 & a \\
\hline & & Z-1-0 & 56 & $\mathrm{~b}_{\mathrm{B}}^{\mathrm{D}}$ & 58 & $a_{B}$ & 72 & $\mathrm{~b}_{\mathrm{A}}^{\mathrm{A}}$ & 62.0 & $\mathrm{a}$ \\
\hline & & Z-0-1 & 44 & $\mathrm{~cd}_{\mathrm{B}}$ & 40 & $\mathrm{~cd}_{\mathrm{C}}$ & 80 & $\mathrm{a}_{\mathrm{A}}$ & 54.7 & $\mathrm{a}$ \\
\hline & & Z-1-1 & 45 & $\mathrm{c}_{\mathrm{B}}^{\mathrm{D}}$ & 60 & ${ }^{\mathrm{a}} \mathrm{A}$ & 61 & $\mathrm{~cd}_{\mathrm{A}}$ & 55.3 & a \\
\hline & & Z-2-1 & 59 & $a_{B}$ & 42 & ${ }^{\mathrm{c}}{ }_{\mathrm{C}}$ & 72 & $\mathrm{~b}_{\mathrm{A}}$ & 57.7 & $\mathrm{a}$ \\
\hline & & Z-2-2 & 41 & $\mathrm{e}^{\mathrm{e}} \mathrm{C}$ & 52 & $\mathrm{~b}_{\mathrm{B}}$ & 58 & $\mathrm{~d}_{\mathrm{A}}$ & 50.3 & a \\
\hline & \multirow{7}{*}{ non-disinfected } & Control & 118 & $\mathrm{bc}_{\mathrm{B}}$ & 180 & ${ }^{\mathrm{a}} \mathrm{A}$ & 109 & $\mathrm{bc}_{\mathrm{B}}$ & 135.7 & $\mathrm{ab}$ \\
\hline & & HT & 101 & $\mathrm{C}_{\mathrm{A}}^{\mathrm{D}}$ & 108 & $\mathrm{~b}_{\mathrm{A}}^{\mathrm{H}}$ & 102 & $\mathrm{bc}_{\mathrm{A}}^{\mathrm{D}}$ & 103.7 & $\mathrm{~b}$ \\
\hline & & $Z-1-0$ & 150 & $\mathrm{ab}_{\mathrm{A}}$ & 182 & ${ }^{a} \mathrm{~A}$ & 157 & ${ }^{\mathrm{a}}{ }_{\mathrm{A}}$ & 163.0 & $\mathrm{ab}$ \\
\hline & & Z-0-1 & 102 & $\mathrm{c}_{\mathrm{A}}$ & 127 & $\mathrm{~b}_{\mathrm{A}}$ & 104 & $\mathrm{c}_{\mathrm{A}}$ & 111.0 & $\mathrm{ab}$ \\
\hline & & Z-1-1 & 136 & $\mathrm{abc}_{\mathrm{B}}$ & 179 & ${ }^{\mathrm{a}} \mathrm{A}$ & 138 & ${ }^{a b c}{ }_{A B}$ & 151.0 & $\mathrm{ab}$ \\
\hline & & Z-2-1 & 165 & $\mathrm{a}_{\mathrm{A}}$ & 189 & ${ }_{\mathrm{A}}^{\mathrm{A}}$ & 151 & $\mathrm{ab}_{\mathrm{A}}$ & 168.3 & a \\
\hline & & $\mathrm{Z}-2-2$ & 136 & $\mathrm{abc}_{\mathrm{A}}$ & 170 & ${ }^{\mathrm{a}} \mathrm{A}$ & 138 & $\mathrm{abc}_{\mathrm{A}}$ & 148.0 & $\mathrm{ab}$ \\
\hline
\end{tabular}

${ }^{1}$ For each object, means followed by the same letter are not statistically different at $\alpha \leq 0.05$ according to Tukey's HSD test; others are. Small letters mark the effect of a given treatment on the total number of fungi within a given year; they refer to column means. Capital letters mark the effect of particular years on the total number of fungi within a given treatment; they refer to row means.

The surface of non-disinfected grains contained more fungal species than that of disinfected grains, with the exception for spring barley grains in 2010 where the values were at the same level (Tables A1-A3). In total, from all the experimental treatments, 18 fungi species were isolated. The disinfected and non-disinfected barley grains contained 14 and 16 fungal species, while pea grains contained 12 and 15, respectively (Figures 1 and 2). 


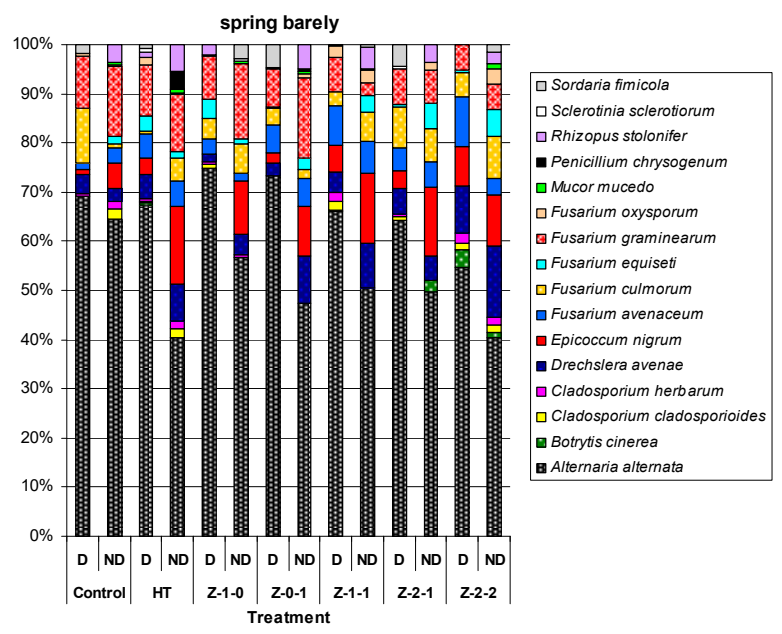

Figure 1. The percentage each species of microscopic fungi cultured for the disinfected (D) and non-disinfected (ND) grains of spring barely, mean for 2010-2012. Mucor mucedo Fresen. and Penicillium chrysogenum Thom were isolated only from non-disinfected (ND) grains.

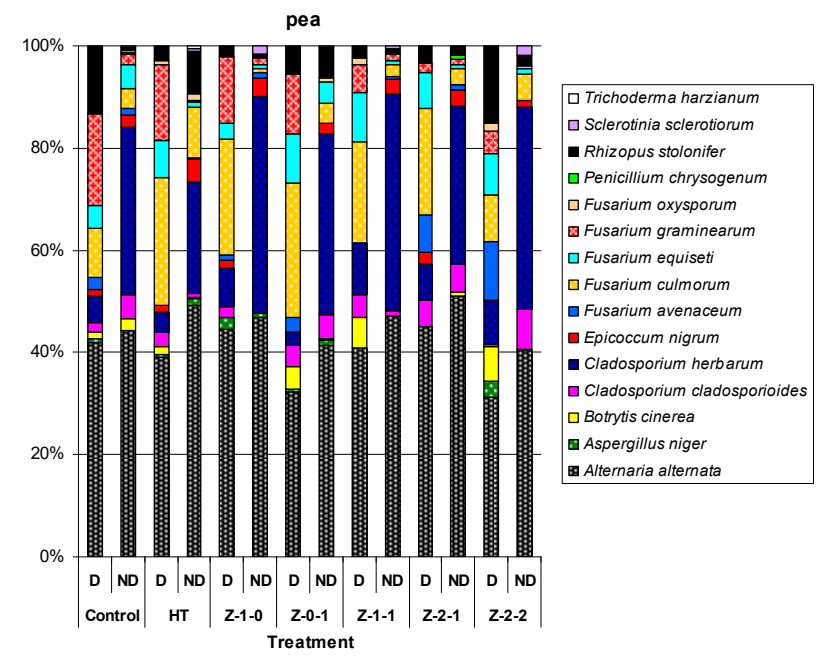

Figure 2. The percentage each species of microscopic fungi cultured for the disinfected (D) and non-disinfected (ND) grains of pea, mean for 2010-2012. Penicillium chrysogenum Thom, Sclerotinia sclerotiorum (Lib.) de Bary and Trichoderma harzianum Rifai were isolated only from non-disinfected (ND) grains.

In all years of the experiment, there were significant differences in the number of fungal species isolated from disinfected and non-disinfected grains (Tables A1-A3). The fungus most frequently isolated from all the treatments and in all years of the study was Alternaria alternata (Fr.) Keissl. which constituted from $54.7 \%$ (Z-2-2) to $74.9 \%$ (Z-1-0) of the total number of isolated fungi for disinfected barley grains, and from 40.4 (HT) to 64.5 (control) for non-disinfected barley grains. Where as, it was from $31.1 \%$ (Z-2-2) to $45.1 \%$ (Z-2-1) for disinfected pea grains, and from $40.3 \%$ (Z-2-2) to $51.1 \%$ (Z-2-1) for non-disinfected pea grains. Penicillium chrysogenum Thom was isolated only from non-disinfected barley and pea grains. On the other hand, Mucor mucedo Fresen. was cultured only from the non-disinfected grains barley, and Trichoderma harzianum Rifai only from the non-disinfected pea grains. However, Sclerotinia sclerotiorum (Lib.) de Bary colonized disinfected and non-disinfected barley grains, and only non-disinfected pea grains (Figures 1 and 2).

We detected some trends and relationships between the intensity of harrowing of the barley-pea mixture using spike-tooth harrow and the mycoflora of grains for components of the mixture (Table 3). Overall, negative correlation was found between the increase in the harrowing intensity and the abundance of fungi cultured from disinfected $(r=-0.48, p=0.2714)$ and non-disinfected $(r=-0.18$, 
$p=0.6970)$ grains of spring barley. In the case of pea grains, the correlation between the intensity of harrowing and the abundance of mycobiota was positive $\left(r_{\text {disinfected grains }}=0.17\right.$ and $p=0.7171$, $r_{\text {non-disinfected grains }}=0.59$ and $\left.p=0.1667\right)$.

\section{Discussion}

Overall, in this study, the moisture of pea grains after harvest was higher than that for spring barley grains. This is possibly due to differences in the morphological structure of these two plant species. It should be noted that moisture content of materials is one of the main factors determining the occurrence of fungi, and the number of colony forming unit of culturable fungi increases as the material's moisture increases [15]. The results of our research confirm this relationship. Moreover, they show the necessity of proper grain storage after harvest in order to maintain their mycological quality.

According to Lejman et al. [2,3], more fungi were isolated from the surface of barley and pea grains grown in a mixture than from the inner layers of these grains. In addition, the mycobiota of non-disinfected grains contained more species than the disinfected ones. The same authors have also reported that mechanical weed control using spring-tine harrow with different intensities does not increase colonization of barley and pea grains by microscopic fungi in mixed cropping of barley and pea. We obtained the same trends in our research growing the same mixture, but using spike-tooth harrow. Furthermore, we show that the abundance of fungi inhabiting the inner layers of barley grains decreased in the case of some treatments (i.e., Z-2-1 and Z-2-2) compared to control and HT treatments. There may be many reasons for this. Nevertheless, most probably harrowing reduces plant density including weeds that can be a reservoir or a pathogen "host" for some fungi, which results in the reduction of humidity between plants. According to the previously mentioned dependence [15], the drop in humidity results in a reduction in the number of fungi. On the other hand, Lejman [22] based his findings on the same experiment, showing that the density of weeds (mean for 2010-2012) in full maturity of a mixture (BBCH 89) decreases with increasing intensity of harrowing using spike-tooth harrow, and a variant of experience in the form of Z-2-1 (47 weeds per $\left.\mathrm{m}^{2}\right)$ is the most optimal treatment. In turn, 100 weeds per $\mathrm{m}^{2}$ were recorded for the control (without harrowing or herbicide application), 86 for HT (herbicide application), 62 for Z-1-0, 63 for Z-0-1, 65 for Z-1-1, and 52 for Z-2-2. Therefore, taking into account the results of our study and those by Lejman [22], it can be concluded that there is a positive trend between the number of weeds and the abundance of fungi isolated from disinfected barley grains. These data confirm the reports on weeds as a potential reservoir of fungi [28,29].

The most frequently isolated fungal species from barley and pea grains after harvest in a pure and mixed sowing is A. alternata $[2,3,30,31]$, and our research further confirms these reports. Overall, these filamentous fungi are typical cosmopolitan species, and they are known as saprobic, endophytic, as well as pathogenic fungi. Especially in their role as plant pathogens they may cause major losses in a wide range of crops, which also occurs after harvest [32]. Furthermore, one of the reasons for the frequent isolation of this species from plants can be its high availability for inoculation in the air. Alternaria species dominate in the atmosphere of various regions of Europe, therefore, the maximum concentration of propagation structures of these fungi in the air is during summer [33]. Moreover, these species, together with other fungi, including Cladosporium ssp., which were isolated in our study, can cause Black Point. This disease can occur on various cereals, and its symptoms appear in the form of grain discoloration, which are mainly visible after harvest. As a consequence, such grains reduce the quality of the flour, leading to its brown color [34].

In the past, harrowing was recommended as a method of reducing weeds only in the early growth stages of crops. It was believed that only at these stages does harrowing not cause damage to the plants of a crop to an extent that would lower its yield, while at the same time efficiently reducing weed infestation [35]. At the moment, it is already known that the efficiency of harrowing is not affected only by the timing of the cultivation but also by many different factors, e.g., number of harrows passages, the working depth of the harrow, soil type, the species and its variety, weather conditions, etc. $[13,20,21,36]$. We can conclude on the basis of our study and others [22] that mechanical weed 
control using spike-tooth harrow with appropriately selected intensity reduces weed infestation in the barley-pea intercrop, but does not significantly reduce grain yield of the component species and the harvest index of the mixture. Furthermore, it does not cause deterioration of mycological quality of both components as compared to both the control without harrowing and herbicidal control. Thus, our research confirms reports that mechanical cultivation may be seen as an alternative to chemical weed control leading to the reduction of pesticides in agriculture $[2,3,37]$.

\section{Conclusions}

This study contributes to a better understanding of the relationships between different intensities of harrowing with spike-tooth harrow in the barley-pea mixture, grain yield of the component species, and microscopic fungi after harvest. We conclude that harrowing in barley-pea intercrops does not reduce the yield of either mixture components, either in grain quantity or in mycological quality, after harvest compared to control without harrowing and control using the herbicide MCPA (Chwastox Extra 340SL). However, increasing the intensity of harrowing did not result in a consistently larger crop yield or reduction in fungal abundance in the grains. Regardless of treatment, the internal structures and surface of both barley and pea grains were colonized to a large extent by cosmopolitan fungi, of which A. alternata was the most abundant. The number of colony forming units of culturable fungi were found to increase with increasing grain moisture. In the near future, we intend to expand our research on the characteristics of entomophages, as well as introduce other plant mixtures and varieties in order to thoroughly characterize this topic.

Author Contributions: R.O. performed the analysis and wrote the paper; A.L. designed the experiment, collected all the samples (fieldwork) and wrote the paper; And P.S. designed the experiment. All the authors revised the paper and approved the final version.

Funding: This research was funded by the Ministry of Science and Higher Education carried out by the University of Wroclaw "Grant to Young Researchers", grant number: 0420/2557/18.

Conflicts of Interest: The authors declare no conflict of interest. 


\section{Appendix A}

Table A1. The average number of fungi isolated from disinfected and non-disinfected grains of spring barley and pea in 2010 (CFU per 100 grains).

\begin{tabular}{|c|c|c|c|c|c|c|c|c|c|}
\hline & & \multirow{2}{*}{ Fungi Species } & \multicolumn{7}{|c|}{ Treatment } \\
\hline & & & Control & HT & Z-1-0 & $\mathrm{Z}-0-1$ & Z-1-1 & Z-2-1 & $\mathrm{Z}-2-2$ \\
\hline \multirow{2}{*}{ Spring barley } & disinfected & $\begin{array}{c}\text { Alternaria alternata (Fr.) Keissl. } \\
\text { Botrytis cinerea Pers. } \\
\text { Cladosporium cladosporioides (Fresen.) G.A. de Vries } \\
\text { Cladosporium herbarum (Pers.) Link } \\
\text { Drechslera avenae (Eidam) S. Ito } \\
\text { Epicoccum nigrum Link } \\
\text { Fusarium avenaceum (Fr.) Sacc. } \\
\text { Fusarium culmorum (W.G. Sm.) Sacc. } \\
\text { Fusarium equiseti (Corda) Sacc. } \\
\text { Fusarium graminearum Schwabe } \\
\text { Fusarium oxysporum Schltdl. } \\
\text { Rhizopus stolonifer (Ehrenb.) Vuill. } \\
\text { Sclerotinia sclerotiorum (Lib.) de Bary } \\
\text { Sordaria fimicola (Roberge ex Desm.) Ces. \& De Not. }\end{array}$ & $\begin{array}{l}60{ }^{\mathrm{a}} \mathrm{C}^{1} \\
0{ }^{\mathrm{e}} \mathrm{A} \\
0{ }^{\mathrm{e}} \mathrm{A} \\
2{ }^{\mathrm{d}}{ }_{\mathrm{B}} \\
0{ }^{\mathrm{e}} \mathrm{C} \\
1{ }^{\mathrm{de}} \mathrm{DE} \\
1{ }^{\mathrm{de}}{ }_{\mathrm{D}} \\
10^{\mathrm{b}} \mathrm{A} \\
0^{\mathrm{e}}{ }_{\mathrm{C}} \\
8^{\mathrm{c}} \mathrm{AB} \\
1{ }^{\mathrm{de}}{ }_{\mathrm{AB}} \\
0{ }^{\mathrm{e}} \mathrm{C} \\
0{ }^{\mathrm{e}} \mathrm{B} \\
1{ }^{\mathrm{de}} \mathrm{AB}\end{array}$ & 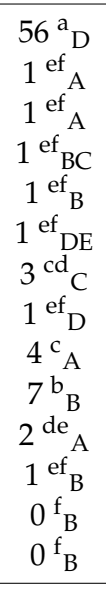 & 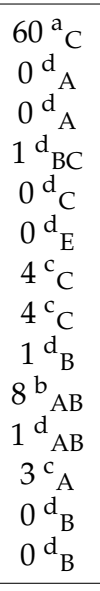 & $\begin{array}{c}75^{\mathrm{a}} \mathrm{A} \\
0 \mathrm{~g}_{\mathrm{A}} \\
0 \mathrm{~g}_{\mathrm{A}} \\
0 \mathrm{~g}_{\mathrm{C}} \\
0 \mathrm{~g}_{\mathrm{C}} \\
3^{\mathrm{de}_{\mathrm{BC}}} \\
7^{\mathrm{b}}{ }_{\mathrm{B}} \\
4^{\mathrm{cd}} \mathrm{C} \\
1^{\mathrm{fg}} \mathrm{B} \\
5^{\mathrm{c}} \mathrm{C} \\
0{ }^{\mathrm{g}}{ }_{\mathrm{B}} \\
0{ }^{\mathrm{g}} \mathrm{C} \\
1^{\mathrm{fg}} \mathrm{A} \\
2^{\mathrm{ef}}{ }_{\mathrm{A}}\end{array}$ & $\begin{array}{c}66{ }^{\mathrm{a}}{ }_{\mathrm{B}} \\
1^{\mathrm{ef}}{ }_{\mathrm{A}} \\
1^{\mathrm{ef}}{ }_{\mathrm{A}} \\
55^{\mathrm{b}} \mathrm{A} \\
1^{\mathrm{ef}}{ }_{\mathrm{B}} \\
5{ }^{\mathrm{b}} \mathrm{A} \\
4{ }^{\mathrm{bc}}{ }_{\mathrm{C}} \\
2{ }^{\mathrm{de}}{ }_{\mathrm{D}} \\
0^{\mathrm{f}}{ }_{\mathrm{C}} \\
3^{\mathrm{cd}}{ }_{\mathrm{D}} \\
2^{\mathrm{de}}{ }_{\mathrm{A}} \\
0^{\mathrm{f}} \mathrm{C} \\
0^{\mathrm{f}}{ }_{\mathrm{B}} \\
1^{\mathrm{ef}}{ }_{\mathrm{AB}}\end{array}$ & 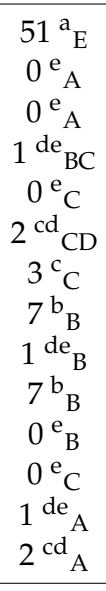 & 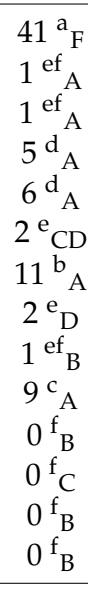 \\
\hline & non-disinfected & $\begin{array}{c}\text { Alternaria alternata (Fr.) Keissl. } \\
\text { Botrytis cinerea Pers. } \\
\text { Cladosporium cladosporioides (Fresen.) G.A. de Vries } \\
\text { Cladosporium herbarum (Pers.) Link } \\
\text { Drechslera avenae (Eidam) S. Ito } \\
\text { Epicoccum nigrum Link } \\
\text { Fusarium avenaceum (Fr.) Sacc. } \\
\text { Fusarium culmorum (W.G. Sm.) Sacc. } \\
\text { Fusarium equiseti (Corda) Sacc. } \\
\text { Fusarium graminearum Schwabe } \\
\text { Fusarium oxysporum Schltdl. } \\
\text { Mucor mucedo Fresen. } \\
\text { Penicillium chrysogenum Thom } \\
\text { Rhizopus stolonifer (Ehrenb.) Vuill. } \\
\text { Sclerotinia sclerotiorum (Lib.) de Bary } \\
\text { Sordaria fimicola (Roberge ex Desm.) Ces. \& De Not. }\end{array}$ & 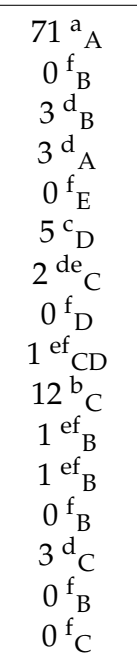 & 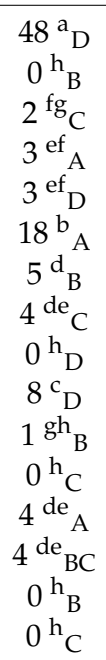 & 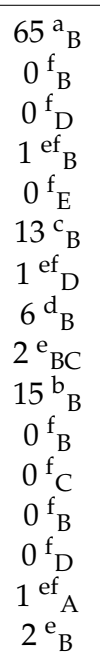 & 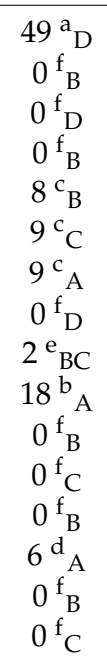 & 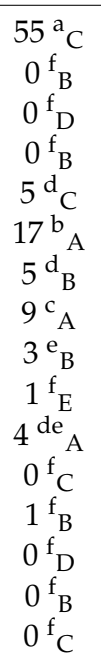 & $\begin{array}{c}49^{\mathrm{a}} \mathrm{D} \\
7^{\mathrm{cd}} \mathrm{A} \\
0 \mathrm{~g}_{\mathrm{D}} \\
0 \mathrm{~g}_{\mathrm{B}} \\
1 \mathrm{~g}_{\mathrm{E}} \\
10^{\mathrm{b}} \mathrm{C} \\
4^{\mathrm{f}}{ }_{\mathrm{B}} \\
8^{\mathrm{c}} \mathrm{A} \\
6^{\mathrm{de}}{ }^{\mathrm{A}} \\
4^{\mathrm{f}} \mathrm{H} \\
5^{\mathrm{ef}}{ }_{\mathrm{A}} \\
0^{\mathrm{g}} \mathrm{C} \\
0^{\mathrm{g}} \mathrm{B} \\
5^{\mathrm{ef}}{ }_{\mathrm{AB}} \\
0^{\mathrm{g}}{ }_{\mathrm{B}} \\
0^{\mathrm{g}} \mathrm{C}\end{array}$ & 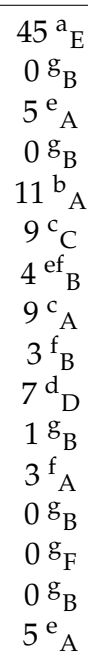 \\
\hline
\end{tabular}


Table A1. Cont.

\begin{tabular}{|c|c|c|c|c|c|c|c|c|c|}
\hline & & \multirow{2}{*}{ Fungi Species } & \multicolumn{7}{|c|}{ Treatment } \\
\hline & & & Control & HT & Z-1-0 & Z-0-1 & Z-1-1 & Z-2-1 & Z-2-2 \\
\hline \multirow{4}{*}{ Pea } & disinfected & $\begin{array}{c}\text { Alternaria alternata (Fr.) Keissl. } \\
\text { Aspergillus niger Tiegh. } \\
\text { Botrytis cinerea Pers. } \\
\text { Cladosporium cladosporioides (Fresen.) G.A. de Vries } \\
\text { Cladosporium herbarum (Pers.) Link } \\
\text { Epicoccum nigrum Link } \\
\text { Fusarium avenaceum (Fr.) Sacc. } \\
\text { Fusarium culmorum (W.G. Sm.) Sacc. } \\
\text { Fusarium equiseti (Corda) Sacc. } \\
\text { Fusarium graminearum Schwabe } \\
\text { Fusarium oxysporum Schltdl. } \\
\text { Rhizopus stolonifer (Ehrenb.) Vuill. }\end{array}$ & 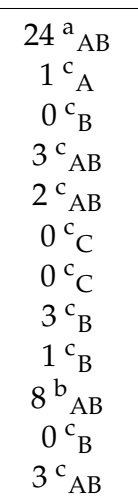 & 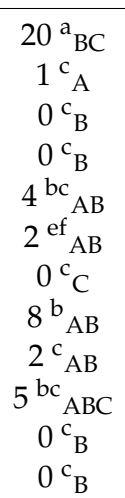 & 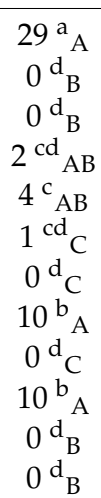 & 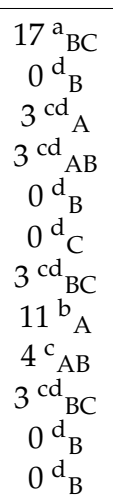 & $\begin{array}{c}18^{\mathrm{a}}{ }_{\mathrm{BC}} \\
0^{\mathrm{d}} \mathrm{d}_{\mathrm{B}} \\
2^{\mathrm{d}} \mathrm{dB} \\
3^{\mathrm{cd}}{ }_{\mathrm{AB}} \\
7^{\mathrm{b}}{ }_{\mathrm{A}} \\
0^{\mathrm{d}}{ }_{\mathrm{C}} \\
0^{\mathrm{d}_{\mathrm{C}}} \\
8^{\mathrm{b}}{ }_{\mathrm{AB}} \\
6^{\mathrm{bc}}{ }_{\mathrm{A}} \\
1^{\mathrm{d}}{ }_{\mathrm{C}} \\
0^{\mathrm{d}_{\mathrm{B}}} \\
0^{\mathrm{d}_{\mathrm{B}}}\end{array}$ & $\begin{array}{c}28^{\mathrm{a}}{ }_{\mathrm{A}} \\
0^{\mathrm{d}_{\mathrm{B}}} \\
0^{\mathrm{d}_{\mathrm{B}}} \\
7^{\mathrm{c}}{ }_{\mathrm{A}} \\
0^{\mathrm{d}_{\mathrm{B}}} \\
4^{\mathrm{cd}}{ }_{\mathrm{A}} \\
13^{\mathrm{b}} \mathrm{A} \\
2^{\mathrm{d}_{\mathrm{B}}} \\
4^{\mathrm{cd}}{ }_{\mathrm{AB}} \\
1^{\mathrm{d}_{\mathrm{C}}} \\
0^{\mathrm{d}_{\mathrm{B}}} \\
0^{\mathrm{d}_{\mathrm{B}}}\end{array}$ & $\begin{array}{c}15^{\mathrm{a}}{ }_{\mathrm{C}} \\
1^{\mathrm{bc}}{ }^{\mathrm{A}} \\
2^{\mathrm{bc}}{ }_{\mathrm{AB}} \\
1^{\mathrm{bc}} \mathrm{B}^{\mathrm{B}} \\
5^{\mathrm{bc}}{ }^{\mathrm{AB}} \\
0^{\mathrm{c}}{ }_{\mathrm{C}} \\
6^{\mathrm{b}}{ }_{\mathrm{B}} \\
2^{\mathrm{bc}}{ }^{\mathrm{B}} \\
2^{\mathrm{bc}}{ }^{\mathrm{AB}} \\
1^{\mathrm{bc}}{ }^{\mathrm{C}} \\
1^{\mathrm{bc}}{ }_{\mathrm{A}} \\
5^{\mathrm{bc}}{ }_{\mathrm{A}}\end{array}$ \\
\hline & \multirow{3}{*}{ non-disinfected } & $\begin{array}{c}\text { Alternaria alternata (Fr.) Keissl. } \\
\text { Aspergillus niger Tiegh. } \\
\text { Botrytis cinerea Pers. } \\
\text { Cladosporium cladosporioides (Fresen.) G.A. de Vries } \\
\text { Cladosporium herbarum (Pers.) Link } \\
\text { Epicoccum nigrum Link } \\
\text { Fusarium avenaceum (Fr.) Sacc. }\end{array}$ & $\begin{array}{l}53^{\mathrm{a}}{ }_{\mathrm{D}} \\
0^{\mathrm{d}}{ }_{\mathrm{B}} \\
3^{\mathrm{cd}}{ }_{\mathrm{A}} \\
7^{\mathrm{c}}{ }_{\mathrm{BC}} \\
38^{\mathrm{b}}{ }_{\mathrm{BC}} \\
4^{\mathrm{cd}}{ }_{\mathrm{AB}} \\
0^{\mathrm{d}_{\mathrm{B}}}\end{array}$ & $\begin{array}{l}47^{\mathrm{a}} \mathrm{E} \\
2{ }^{\mathrm{def}}{ }_{\mathrm{A}} \\
0^{\mathrm{f}} \mathrm{B} \\
2{ }^{\mathrm{def}} \mathrm{CD} \\
22{ }^{\mathrm{b}} \mathrm{C} \\
7{ }^{\mathrm{cd}} \mathrm{A} \\
1{ }^{\mathrm{ef}} \mathrm{A}\end{array}$ & $\begin{array}{l}71^{\mathrm{a}} \mathrm{B} \\
2^{\mathrm{cd}}{ }_{\mathrm{A}} \\
0^{\mathrm{d}}{ }_{\mathrm{B}} \\
0^{\mathrm{d}} \mathrm{D} \\
62^{\mathrm{b}} \mathrm{A} \\
6^{\mathrm{c}} \mathrm{AB} \\
1^{\mathrm{cd}} \mathrm{A}\end{array}$ & $\begin{array}{l}44^{\mathrm{a}} \\
1^{\mathrm{cd}}{ }_{\mathrm{AB}} \\
0^{\mathrm{d}}{ }_{\mathrm{B}} \\
8^{\mathrm{c}}{ }_{\mathrm{BC}} \\
33^{\mathrm{b}}{ }_{\mathrm{BC}} \\
3^{\mathrm{cd}}{ }^{\mathrm{B}} \\
0^{\mathrm{d}_{\mathrm{B}}}\end{array}$ & $\begin{array}{l}67^{\mathrm{a}} \mathrm{C} \\
1{ }^{\mathrm{c}} \mathrm{AB} \\
0^{\mathrm{c}}{ }_{\mathrm{B}} \\
0^{\mathrm{c}}{ }_{\mathrm{D}} \\
59^{\mathrm{b}} \mathrm{A} \\
5^{\mathrm{c}} \mathrm{AB} \\
0^{\mathrm{c}}{ }_{\mathrm{B}}\end{array}$ & $\begin{array}{l}83^{\mathrm{a}} \mathrm{A} \\
0{ }^{\mathrm{e}} \mathrm{B} \\
2^{\mathrm{de}}{ }_{\mathrm{A}} \\
12^{\mathrm{c}} \mathrm{AB} \\
47^{\mathrm{b}} \mathrm{AB} \\
7^{\mathrm{cd}}{ }_{\mathrm{A}} \\
1^{\mathrm{e}}{ }_{\mathrm{A}}\end{array}$ & $\begin{array}{l}55^{\mathrm{a}} \mathrm{D} \\
1^{\mathrm{cd}}{ }_{\mathrm{AB}} \\
0^{\mathrm{d}}{ }_{\mathrm{B}} \\
15^{\mathrm{b}}{ }_{\mathrm{A}} \\
51^{\mathrm{a}}{ }_{\mathrm{AB}} \\
3^{\mathrm{cd}}{ }_{\mathrm{B}} \\
0^{\mathrm{d}_{\mathrm{B}}}\end{array}$ \\
\hline & & Fusarium culmorum (W.G. Sm.) Sacc. & $1^{\mathrm{cd}} \mathrm{C}$ & $9^{c} \mathrm{~A}$ & $0^{d}{ }_{C}$ & $3^{\mathrm{cd}}{ }_{\mathrm{BC}}$ & $1{ }^{\mathrm{c}} \mathrm{C}$ & $\mathrm{de}_{\mathrm{ABC}}^{4}$ & $7^{\mathrm{c}} \mathrm{AB}$ \\
\hline & & $\begin{array}{l}\text { Fusarium equiseti (Corda) Sacc. } \\
\text { Fusarium graminearum Schwabe } \\
\text { Fusarium oxysporum Schltdl. } \\
\text { Penicillium chrysogenum Thom } \\
\text { Rhizopus stolonifer (Ehrenb.) Vuill. } \\
\text { Sclerotinia sclerotiorum (Lib.) de Bary }\end{array}$ & $\begin{array}{l}7_{\mathrm{A}}^{\mathrm{c}} \\
3^{\mathrm{cd}} \mathrm{A} \\
1^{\mathrm{cd}}{ }_{\mathrm{A}} \\
0^{\mathrm{d}}{ }_{\mathrm{B}} \\
1^{\mathrm{cd}}{ }_{\mathrm{AB}} \\
0^{\mathrm{d}}{ }_{\mathrm{B}}\end{array}$ & $\begin{array}{l}3{ }^{\text {def }} \mathrm{AB} \\
1{ }^{\mathrm{ef}}{ }_{\mathrm{B}} \\
0{ }_{\mathrm{B}}^{\mathrm{B}} \\
0{ }_{\mathrm{B}}^{\mathrm{B}} \\
6^{\mathrm{cde}} \mathrm{A} \\
1^{\mathrm{ef}} \mathrm{AB}\end{array}$ & $\begin{array}{l}0^{\mathrm{d}_{\mathrm{B}}} \\
4^{\mathrm{cd}}{ }_{\mathrm{A}} \\
0^{\mathrm{d}_{\mathrm{B}}} \\
0^{\mathrm{d}_{\mathrm{B}}} \\
0^{\mathrm{d}_{\mathrm{B}}} \\
4^{\mathrm{cd}}{ }_{\mathrm{A}}\end{array}$ & $\begin{array}{l}6^{\mathrm{cd}}{ }_{\mathrm{AB}} \\
0^{\mathrm{d}_{\mathrm{B}}} \\
0^{\mathrm{d}_{\mathrm{B}}} \\
0^{\mathrm{d}_{\mathrm{B}}} \\
4^{\mathrm{d}}{ }_{\mathrm{AB}} \\
0 \mathrm{~d}_{\mathrm{B}}\end{array}$ & $\begin{array}{l}1{ }^{\mathrm{c}} \mathrm{AB} \\
0{ }^{\mathrm{C}}{ }_{\mathrm{B}} \\
0{ }^{\mathrm{C}}{ }_{\mathrm{B}} \\
0{ }^{\mathrm{C}}{ }_{\mathrm{B}} \\
0^{\mathrm{C}}{ }_{\mathrm{B}} \\
2^{\mathrm{c}} \mathrm{AB}\end{array}$ & $\begin{array}{c}0 \mathrm{e}_{\mathrm{B}}^{\mathrm{ADC}} \\
3{ }^{\mathrm{de}}{ }_{\mathrm{A}} \\
0 \mathrm{e}_{\mathrm{B}} \\
1{ }^{\mathrm{e}} \mathrm{A} \\
5{ }^{\mathrm{de}}{ }_{\mathrm{AB}} \\
0{ }^{\mathrm{e}}{ }_{\mathrm{B}}\end{array}$ & $\begin{array}{l}0^{\mathrm{d}_{\mathrm{B}}} \\
0^{\mathrm{d}}{ }_{\mathrm{B}} \\
1^{\mathrm{cd}} \mathrm{A} \\
0^{\mathrm{d}}{ }_{\mathrm{B}} \\
1^{\mathrm{cd}}{ }_{\mathrm{AB}} \\
2^{\mathrm{cd}} \mathrm{AB}\end{array}$ \\
\hline
\end{tabular}

For each treatment, means followed by the same letter are not statistically different at $\alpha \leq 0.05$ according to Tukey's HSD test. Sm
given year; they refer to column means. Capital letters mark the effect of years within a given treatment; they refer to row means. 
Table A2. The average number of fungi isolated from disinfected and non-disinfected grains of spring barley and pea in 2011 (CFU per 100 grains).

\begin{tabular}{|c|c|c|c|c|c|c|c|c|c|}
\hline & & \multirow{2}{*}{ Fungi Species } & \multicolumn{7}{|c|}{ Treatment } \\
\hline & & & Control & HT & Z-1-0 & Z-0-1 & Z-1-1 & $Z-2-1$ & $\mathrm{Z}-2-2$ \\
\hline \multirow[b]{2}{*}{ Spring barley } & disinfected & $\begin{array}{c}\text { Alternaria alternata (Fr.) Keissl. } \\
\text { Botrytis cinerea Pers. } \\
\text { Cladosporium cladosporioides (Fresen.) G.A. de Vries } \\
\text { Epicoccum nigrum Link } \\
\text { Fusarium avenaceum (Fr.) Sacc. } \\
\text { Fusarium culmorum (W.G. Sm.) Sacc. } \\
\text { Fusarium equiseti (Corda) Sacc. } \\
\text { Fusarium graminearum Schwabe } \\
\text { Rhizopus stolonifer (Ehrenb.) Vuill. } \\
\text { Sordaria fimicola (Roberge ex Desm.) Ces. \& De Not. }\end{array}$ & 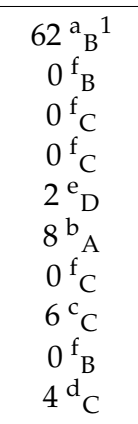 & $\begin{array}{l}60{ }^{\mathrm{a}} \mathrm{C} \\
0{ }^{\mathrm{e}}{ }_{\mathrm{B}} \\
0{ }^{\mathrm{e}} \mathrm{C} \\
0{ }^{\mathrm{e}} \mathrm{C} \\
4{ }^{\mathrm{c}}{ }_{\mathrm{C}} \\
0{ }^{\mathrm{e}} \mathrm{E} \\
4{ }^{\mathrm{c}}{ }_{\mathrm{B}} \\
12{ }^{\mathrm{b}} \mathrm{A} \\
2{ }^{\mathrm{d}}{ }_{\mathrm{A}} \\
0{ }^{\mathrm{e}}{ }_{\mathrm{D}}\end{array}$ & $\begin{array}{l}52^{\mathrm{a}} \mathrm{E} \\
0{ }^{\mathrm{e}}{ }_{\mathrm{B}} \\
2 \mathrm{~d}^{\mathrm{d}} \\
0{ }^{\mathrm{e}} \mathrm{C} \\
4^{\mathrm{C}}{ }_{\mathrm{C}}^{\mathrm{C}} \\
0{ }^{\mathrm{e}} \mathrm{E} \\
9^{\mathrm{b}}{ }_{\mathrm{A}} \\
2{ }^{\mathrm{d}} \mathrm{D} \\
0 \mathrm{e}^{\mathrm{e}} \\
0{ }^{\mathrm{e}} \mathrm{D}\end{array}$ & $\begin{array}{l}78^{\mathrm{a}} \mathrm{A} \\
0{ }^{\mathrm{e}}{ }_{\mathrm{B}} \\
0^{\mathrm{e}}{ }_{\mathrm{C}} \\
1 \mathrm{de}_{\mathrm{BC}} \\
4{ }^{\mathrm{c}} \mathrm{C} \\
2{ }^{\mathrm{d}}{ }_{\mathrm{D}} \\
0^{\mathrm{e}}{ }_{\mathrm{C}} \\
2^{\mathrm{d}}{ }_{\mathrm{D}} \\
0^{\mathrm{e}}{ }_{\mathrm{B}} \\
12^{\mathrm{b}}{ }_{\mathrm{A}}\end{array}$ & $\begin{array}{c}56^{\mathrm{a}} \mathrm{D} \\
0^{\mathrm{f}}{ }_{\mathrm{B}} \\
4^{\mathrm{d}}{ }_{\mathrm{A}} \\
2 \mathrm{e}^{\mathrm{B}} \\
6^{\mathrm{c}}{ }_{\mathrm{B}} \\
4^{\mathrm{d}}{ }_{\mathrm{C}} \\
0^{\mathrm{f}}{ }_{\mathrm{C}} \\
8^{\mathrm{b}}{ }_{\mathrm{B}} \\
0^{\mathrm{f}}{ }_{\mathrm{B}} \\
0^{\mathrm{f}}{ }_{\mathrm{D}}\end{array}$ & 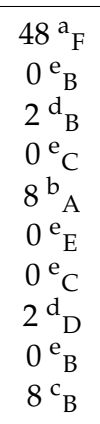 & $\begin{array}{l}42^{\mathrm{a}} \mathrm{G} \\
8^{\mathrm{c}}{ }_{\mathrm{A}} \\
2 \mathrm{e}^{\mathrm{e}} \\
12^{\mathrm{b}}{ }_{\mathrm{A}} \\
2^{\mathrm{e}}{ }_{\mathrm{D}} \\
6^{\mathrm{d}}{ }^{\mathrm{B}} \\
0^{\mathrm{f}} \mathrm{C} \\
2^{\mathrm{e}}{ }_{\mathrm{D}} \\
0^{\mathrm{f}} \mathrm{f}_{\mathrm{B}} \\
0^{\mathrm{f}}{ }_{\mathrm{D}}\end{array}$ \\
\hline & non-disinfected & $\begin{array}{c}\text { Alternaria alternata (Fr.) Keissl. } \\
\text { Botrytis cinerea Pers. } \\
\text { Cladosporium cladosporioides (Fresen.) G.A. de Vries } \\
\text { Cladosporium herbarum (Pers.) Link } \\
\text { Epicoccum nigrum Link } \\
\text { Fusarium avenaceum (Fr.) Sacc. } \\
\text { Fusarium culmorum (W.G. Sm.) Sacc. } \\
\text { Fusarium equiseti (Corda) Sacc. } \\
\text { Fusarium graminearum Schwabe } \\
\text { Fusarium oxysporum Schltdl. } \\
\text { Mucor mucedo Fresen. } \\
\text { Penicillium chrysogenum Thom } \\
\text { Rhizopus stolonifer (Ehrenb.) Vuill. } \\
\text { Sordaria fimicola (Roberge ex Desm.) Ces. \& De Not. }\end{array}$ & 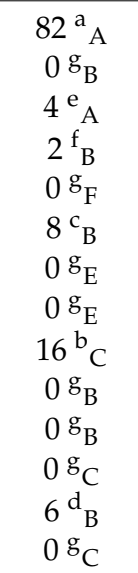 & 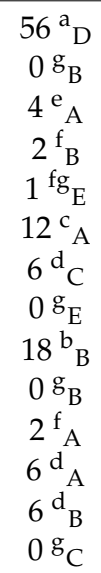 & 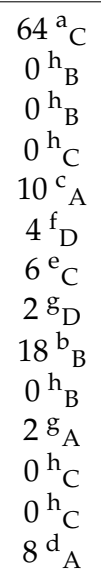 & 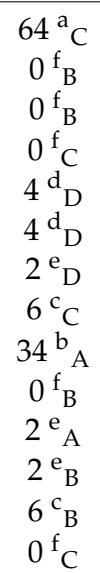 & 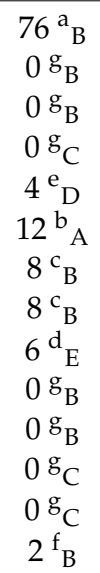 & 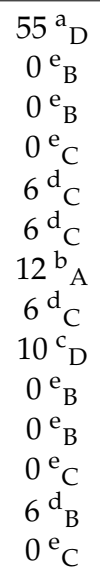 & 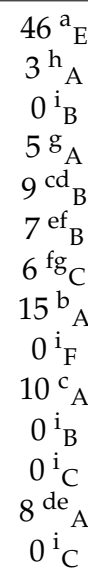 \\
\hline
\end{tabular}


Table A2. Cont.

\begin{tabular}{|c|c|c|c|c|c|c|c|c|c|}
\hline & & \multirow{2}{*}{ Fungi Species } & \multicolumn{7}{|c|}{ Treatment } \\
\hline & & & Control & HT & Z-1-0 & $\mathrm{Z}-0-1$ & Z-1-1 & $\mathrm{Z}-2-1$ & $\mathrm{Z}-2-2$ \\
\hline \multirow{23}{*}{ Pea } & \multirow{11}{*}{ disinfected } & Alternaria alternata (Fr.) Keissl. & $22^{\mathrm{a}} \mathrm{AB}$ & $13^{a}{ }_{B}$ & $32^{\mathrm{a}} \mathrm{AB}$ & $20^{a}{ }_{B}$ & $42^{\mathrm{a}} \mathrm{A}$ & $20^{a}{ }_{B}$ & $18^{\mathrm{a}}{ }_{\mathrm{B}}$ \\
\hline & & Aspergillus niger Tiegh. & $0 \mathrm{c}_{\mathrm{B}}$ & $0^{c}{ }_{B}$ & $4{ }^{\mathrm{b}} \mathrm{A}$ & $1^{\mathrm{c}} \mathrm{AB}$ & $0^{\mathrm{c}} \mathrm{B}_{\mathrm{B}}$ & $0^{\mathrm{c}}{ }_{\mathrm{B}}$ & $4{ }^{\mathrm{bc}} \mathrm{A}$ \\
\hline & & Botrytis cinerea Pers. & $2{ }^{\mathrm{bc}} \mathrm{AB}$ & $0{ }^{c}{ }_{B}$ & $0^{b}{ }_{B}$ & $0{ }^{c}{ }_{B}$ & $0^{c}{ }_{B}$ & $0^{\mathrm{c}}{ }_{\mathrm{B}}$ & $4^{\mathrm{bc}} \mathrm{A}$ \\
\hline & & Cladosporium cladosporioides (Fresen.) G.A. de Vries & $0{ }^{c}{ }_{B}$ & $2^{\mathrm{c}} \mathrm{AB}$ & $2^{\mathrm{b}} \mathrm{AB}$ & $2^{\mathrm{c}} \mathrm{AB}$ & $4^{\mathrm{bc}} \mathrm{A}$ & $2^{\mathrm{c}} \mathrm{AB}$ & $0^{c}{ }_{B}$ \\
\hline & & Cladosporium herbarum (Pers.) Link & $6^{\mathrm{bc}} \mathrm{AB}$ & $1^{\mathrm{c}}{ }_{\mathrm{B}}$ & $8^{\mathrm{b}} \mathrm{AB}$ & $4{ }^{\mathrm{bc}} \mathrm{AB}$ & $10^{\mathrm{b}} \mathrm{AB}$ & $12^{\mathrm{b}} \mathrm{A}$ & $4^{\mathrm{bc}} \mathrm{AB}$ \\
\hline & & Epicoccum nigrum Link & $2{ }^{\mathrm{bc}} \mathrm{A}$ & $0^{\mathrm{c}}{ }_{\mathrm{B}}$ & $2{ }^{b} \mathrm{~A}$ & $0^{\mathrm{c}}{ }_{\mathrm{B}}$ & $0^{\mathrm{c}}{ }_{\mathrm{B}}$ & $0^{\mathrm{C}} \mathrm{B}$ & $0^{\mathrm{c}} \mathrm{B}_{\mathrm{B}}$ \\
\hline & & Fusarium avenaceum (Fr.) Sacc. & $4 \mathrm{bc}_{\mathrm{B}}$ & $0{ }^{c}{ }_{B}$ & $2^{b}{ }_{B}$ & $0^{c}{ }_{B}$ & $0^{c}{ }^{c}$ & $0^{c}{ }_{B}$ & $10^{\mathrm{ab}} \mathrm{A}$ \\
\hline & & Fusarium culmorum (W.G. Sm.) Sacc. & $0^{c_{B}}$ & $2^{\mathrm{c}} \mathrm{A}$ & $0 \mathrm{~b}_{\mathrm{B}}$ & $0^{\mathrm{c}}{ }_{\mathrm{B}}$ & $0^{\mathrm{c}}{ }_{\mathrm{B}}$ & $0^{\mathrm{c}}{ }_{\mathrm{B}}$ & $0^{\mathrm{c}}{ }_{\mathrm{B}}$ \\
\hline & & Fusarium equiseti (Corda) Sacc. & $2^{\mathrm{bc}} \mathrm{AB}$ & $5{ }^{b c} \mathrm{~A}$ & $0^{b}{ }_{B}$ & $0^{c}{ }_{B}$ & $0^{\mathrm{c}}{ }_{\mathrm{B}}$ & $0^{\mathrm{c}}{ }_{\mathrm{B}}$ & $0{ }^{c}{ }_{B}$ \\
\hline & & Fusarium graminearum Schwabe & $4{ }^{\mathrm{bc}}{ }_{\mathrm{BC}}$ & $12^{\mathrm{ab}} \mathrm{A}$ & $8^{\mathrm{b}} \mathrm{ABC}$ & $10^{\mathrm{b}} \mathrm{AB}$ & $4^{\mathrm{bc}}{ }_{\mathrm{BC}}$ & $2{ }^{\mathrm{C}} \mathrm{C}$ & $2{ }^{\mathrm{bc}} \mathrm{C}$ \\
\hline & & Rhizopus stolonifer (Ehrenb.) Vuill. & $8^{b} \mathrm{AB}$ & $2^{\mathrm{C}}{ }_{\mathrm{BC}}$ & $0^{\mathrm{b}} \mathrm{C}$ & $3^{\mathrm{c}} \mathrm{ABC}$ & $0{ }^{\mathrm{c}} \mathrm{C}$ & $6^{\mathrm{bc}} \mathrm{ABC}$ & $10^{\mathrm{ab}} \mathrm{A}$ \\
\hline & \multirow{12}{*}{ non-disinfected } & Alternaria alternata (Fr.) Keissl. & $88^{\mathrm{a}} \mathrm{A}$ & $52^{\mathrm{a}} \mathrm{AB}$ & $78^{\mathrm{a}} \mathrm{AB}$ & $50^{a}{ }_{B}$ & $72{ }^{b} \mathrm{AB}$ & $89^{a} \mathrm{~A}$ & $72^{\mathrm{a}} \mathrm{AB}$ \\
\hline & & Aspergillus niger Tiegh. & $0^{\mathrm{c}}{ }_{\mathrm{B}}$ & $2^{\mathrm{cd}} \mathrm{A}$ & $2 \mathrm{~b}_{\mathrm{A}}$ & $0^{\mathrm{c}}{ }_{\mathrm{B}}$ & $0^{\mathrm{c}}{ }_{\mathrm{B}}$ & $0^{\mathrm{d}_{B}}$ & $0^{\mathrm{c}}{ }_{\mathrm{B}}$ \\
\hline & & Botrytis cinerea Pers. & $0{ }^{c}{ }_{B}$ & $1^{\mathrm{cd}}$ & $0^{b}{ }_{B}$ & $0^{c}{ }_{B}$ & $0^{c_{B}}$ & $0^{d_{B}}$ & $0^{\mathrm{c}}{ }_{\mathrm{B}}$ \\
\hline & & Cladosporium cladosporioides (Fresen.) G.A. de Vries & $10_{\mathrm{B}}$ & $0^{d_{C}}$ & $0^{b}{ }_{C}$ & $0^{\mathrm{c}}{ }_{\mathrm{C}}$ & $0^{\mathrm{c}}{ }_{\mathrm{C}}$ & $15^{\mathrm{c}} \mathrm{A}$ & $12^{\mathrm{b}} \mathrm{AB}$ \\
\hline & & Cladosporium herbarum (Pers.) Link & $69^{\mathrm{b}} \mathrm{AB}$ & $37^{\mathrm{b}} \mathrm{C}$ & $87^{\mathrm{a}} \mathrm{A}$ & $55^{a}{ }_{B}$ & $88^{\mathrm{a}} \mathrm{A}$ & $76^{\mathrm{b}} \mathrm{A}$ & $73^{\mathrm{a}} \mathrm{AB}$ \\
\hline & & Epicoccum nigrum Link & $3^{\mathrm{c}} \mathrm{A}$ & $4{ }^{\mathrm{cd}} \mathrm{A}$ & $5^{\mathrm{b}} \mathrm{A}$ & $4^{\mathrm{c}} \mathrm{A}$ & $8^{\mathrm{c}} \mathrm{A}$ & $6^{\mathrm{cd}} \mathrm{A}$ & $3^{\mathrm{bc}} \mathrm{A}$ \\
\hline & & Fusarium avenaceum (Fr.) Sacc. & $4^{\mathrm{c}} \mathrm{A}$ & $0 \mathrm{~d}_{\mathrm{B}}$ & $4 \mathrm{~b}_{\mathrm{A}}^{\mathrm{b}}$ & $0^{\mathrm{c}}{ }_{\mathrm{B}}$ & $0^{c}{ }_{B}$ & $0^{\mathrm{d}}{ }_{B}$ & $0^{\mathrm{c}}{ }_{\mathrm{B}}$ \\
\hline & & Fusarium culmorum (W.G. Sm.) Sacc. & $0{ }^{c}{ }_{B}$ & $0^{\mathrm{d}}{ }_{\mathrm{B}}$ & $0 \mathrm{~b}_{\mathrm{B}}$ & $0^{c}{ }_{B}$ & $0^{\mathrm{c}}{ }_{\mathrm{B}}$ & $0^{d}{ }_{B}$ & $2^{\mathrm{bc}} \mathrm{A}$ \\
\hline & & Fusarium equiseti (Corda) Sacc. & $4^{\mathrm{c}} \mathrm{A}$ & $0^{d_{C}}$ & $0{ }^{b} \mathrm{C}$ & $2{ }^{c}{ }_{B}$ & $0{ }^{\mathrm{c}} \mathrm{C}$ & $0^{d_{C}}$ & $0{ }^{\mathrm{c}} \mathrm{C}$ \\
\hline & & Fusarium graminearum Schwabe & $0^{\mathrm{c}} \mathrm{C}$ & $0^{\mathrm{d}_{C}}$ & $2 b_{B}$ & $0{ }^{\mathrm{c}} \mathrm{C}$ & $6^{\mathrm{c}} \mathrm{A}$ & $0^{\mathrm{d}_{C}}$ & $0{ }^{\mathrm{c}} \mathrm{C}$ \\
\hline & & Penicillium chrysogenum Thom & $2{ }^{\mathrm{C}} \mathrm{AB}$ & $0^{d_{C}}$ & $0{ }^{\mathrm{b}} \mathrm{C}$ & $0^{\mathrm{c}}{ }_{\mathrm{C}}$ & $1^{\mathrm{c}}{ }_{\mathrm{BC}}$ & $3^{\mathrm{cd}} \mathrm{A}$ & $0{ }^{\mathrm{c}} \mathrm{C}$ \\
\hline & & Rhizopus stolonifer (Ehrenb.) Vuill. & $0^{\mathrm{c}} \mathrm{A}$ & $12^{\mathrm{c}} \mathrm{B}$ & $4{ }^{b} \mathrm{D}$ & $16^{\mathrm{b}} \mathrm{A}$ & $4^{\mathrm{c}} \mathrm{D}$ & $0^{\mathrm{d}} \mathrm{A}$ & $8{ }^{\mathrm{bc}} \mathrm{C}$ \\
\hline
\end{tabular}

${ }^{1}$ For each treatment, means followed by the same letter are not statistically different at $\alpha \leq 0.05$ according to Tukey's HSD test. Small letters mark treatment differences between within a given year; they refer to column means. Capital letters mark the effect of years within a given treatment; they refer to row means. 
Table A3. The average number of fungi isolated from disinfected and non-disinfected grains of spring barley in 2012 (CFU per 100 grains).

\begin{tabular}{|c|c|c|c|c|c|c|c|c|c|}
\hline & & \multirow{2}{*}{ Fungi Species } & \multicolumn{7}{|c|}{ Treatment } \\
\hline & & & Control & HT & Z-1-0 & Z-0-1 & Z-1-1 & $Z-2-1$ & $\mathrm{Z}-2-2$ \\
\hline \multirow{20}{*}{ Spring barley } & \multirow{10}{*}{ disinfected } & Alternaria alternata (Fr.) Keissl. & $61^{a} C^{1}$ & $60{ }^{a} \mathrm{C}$ & $76^{\mathrm{a}} \mathrm{A}$ & $66^{\mathrm{a}}{ }_{\mathrm{B}}$ & $58^{\mathrm{a}}{ }_{\mathrm{D}}$ & $48^{\mathrm{a}} \mathrm{F}$ & $52^{\mathrm{a}}{ }_{\mathrm{E}}$ \\
\hline & & Drechslera avenae (Eidam) S. Ito & $10^{\mathrm{d}} \mathrm{C}$ & $12{ }^{b}$ & $4_{\mathrm{E}}^{\mathrm{d}}$ & $8^{\mathrm{c}} \mathrm{D}$ & $10{ }^{\mathrm{c}} \mathrm{C}$ & $12^{b}{ }_{B}$ & $18^{\mathrm{b}}{ }_{\mathrm{A}}^{\mathrm{t}}$ \\
\hline & & Epicoccum nigrum Link & $2{ }^{e} \mathrm{C}$ & $8^{\mathrm{c}} \mathrm{A}$ & $0{ }^{\mathrm{f}} \mathrm{D}$ & $2{ }^{\mathrm{f}} \mathrm{C}$ & $8^{\mathrm{d}} \mathrm{A}$ & $6^{d}{ }_{B}$ & $6^{\mathrm{d}}{ }_{B}$ \\
\hline & & Fusarium avenaceum (Fr.) Sacc. & $0^{\mathrm{f}} \mathrm{C}$ & $6^{d}{ }_{B}$ & $0{ }^{\mathrm{f}} \mathrm{C}$ & $6^{d_{B}}$ & $12{ }^{b} \mathrm{~A}$ & $0 \mathrm{e}_{\mathrm{C}}$ & $12^{\mathrm{c}} \mathrm{A}$ \\
\hline & & Fusarium culmorum (W.G. Sm.) Sacc. & $12^{\mathrm{c}} \mathrm{A}$ & $0^{\mathrm{f}} \mathrm{E}$ & $6^{c}{ }_{B}$ & $4{ }^{\mathrm{e}} \mathrm{C}$ & $2^{\mathrm{f}} \mathrm{D}$ & $12^{\mathrm{b}} \mathrm{A}$ & $4{ }^{\mathrm{e}} \mathrm{C}$ \\
\hline & & Fusarium graminearum Schwabe & $14^{\mathrm{b}}{ }_{\mathrm{B}}$ & $8^{\mathrm{c}} \mathrm{D}$ & $12{ }^{\mathrm{b}} \mathrm{C}$ & $16^{\mathrm{b}} \mathrm{A}$ & $8^{\mathrm{d}} \mathrm{D}$ & $8^{\mathrm{c}} \mathrm{D}$ & $2^{f}{ }_{E}$ \\
\hline & & Fusarium oxysporum Schltdl. & $0{ }^{\mathrm{f}} \mathrm{C}$ & $2 \mathrm{e}_{\mathrm{B}}$ & $0{ }^{\mathrm{f}} \mathrm{C}$ & $0^{g}{ }_{C}$ & $4{ }^{\mathrm{e}} \mathrm{A}$ & $0 \mathrm{e}_{\mathrm{C}}$ & $0^{\mathrm{g}} \mathrm{C}$ \\
\hline & & Rhizopus stolonifer (Ehrenb.) Vuill. & $0{ }_{B}^{f}$ & $0{ }_{B}^{f}$ & $2^{\mathrm{e}} \mathrm{A}$ & $0 \mathrm{~g}_{\mathrm{B}}$ & $0 \mathrm{~g}_{\mathrm{B}}$ & $0 \mathrm{e}_{\mathrm{B}}$ & $0 \mathrm{~g}_{\mathrm{B}}$ \\
\hline & & Sclerotinia sclerotiorum (Lib.) de Bary & $0 \mathrm{f}_{\mathrm{B}}^{\mathrm{D}}$ & $2{ }^{\mathrm{e}} \mathrm{A}$ & $0 \mathrm{f}_{\mathrm{B}}$ & $0 \mathrm{~g}_{\mathrm{B}}$ & $0 \mathrm{~g}_{\mathrm{B}}$ & $0 \mathrm{e}_{\mathrm{B}}^{\mathrm{D}}$ & $0 \mathrm{~g}_{\mathrm{B}}$ \\
\hline & & Sordaria fimicola (Roberge ex Desm.) Ces. \& De Not. & $0 \mathrm{f}_{\mathrm{B}}$ & $2{ }^{\mathrm{f}} \mathrm{A}$ & $0 \mathrm{f}_{\mathrm{B}}$ & $0 \mathrm{~g}_{\mathrm{B}}$ & $0 \mathrm{~g}_{\mathrm{B}}$ & $0{ }^{\mathrm{e}}{ }_{\mathrm{B}}$ & $0 \mathrm{~g}_{\mathrm{B}}$ \\
\hline & \multirow{10}{*}{ non-disinfected } & Alternaria alternata (Fr.) Keissl. & $54^{\mathrm{a}}{ }_{\mathrm{B}}$ & $28 \mathrm{~b}_{\mathrm{F}}$ & $62^{\mathrm{a}} \mathrm{A}$ & $44^{\mathrm{a}} \mathrm{D}$ & $34^{\mathrm{a}}$ & $47^{\mathrm{a}} \mathrm{C}$ & $44^{\mathrm{a}}{ }_{\mathrm{D}}$ \\
\hline & & Drechslera avenae (Eidam) S. Ito & $8^{\mathrm{d}}$ & $22{ }^{\mathrm{C}} \mathrm{C}$ & $14^{\mathrm{C}} \mathrm{D}$ & $24^{\mathrm{b}}{ }_{\mathrm{B}}$ & $24^{\mathrm{C}}{ }_{\mathrm{B}}$ & $14^{\mathrm{C}} \mathrm{D}$ & $38^{\mathrm{b}} \mathrm{A}$ \\
\hline & & Epicoccum nigrum Link & $12^{\mathrm{c}} \mathrm{F}$ & $32^{\mathrm{a}} \mathrm{A}$ & $14^{\mathrm{c}} \mathrm{E}$ & $20{ }^{\mathrm{c}} \mathrm{C}$ & $26^{\mathrm{b}}{ }_{\mathrm{B}}$ & $26^{\mathrm{b}}{ }_{\mathrm{B}}$ & $16^{\mathrm{c}} \mathrm{D}$ \\
\hline & & Fusarium avenaceum (Fr.) Sacc. & $0^{\mathrm{g}} \mathrm{C}_{\mathrm{C}}$ & $0^{\mathrm{h}} \mathrm{C}$ & $0{ }^{e}{ }_{C}$ & $6^{\mathrm{d}} \mathrm{A}$ & $4_{B}^{e}$ & $6^{\mathrm{d}} \mathrm{A}$ & $0{ }^{\mathrm{f}} \mathrm{C}$ \\
\hline & & Fusarium culmorum (W.G. Sm.) Sacc. & $2^{f}{ }_{E}$ & $6^{\mathrm{f}} \mathrm{C}$ & $8^{d_{B}}$ & $4 \mathrm{e}_{\mathrm{D}}^{\mathrm{e}}$ & $2{ }^{f} \mathrm{E}$ & $0 \mathrm{f}_{\mathrm{F}}$ & $14^{\mathrm{d}} \mathrm{A}$ \\
\hline & & Fusarium equiseti (Corda) Sacc. & $4{ }^{\mathrm{e}} \mathrm{A}$ & $4^{\mathrm{g}} \mathrm{A}$ & $0^{\mathrm{e}}{ }_{\mathrm{B}}$ & $0 \mathrm{~g}_{\mathrm{B}}$ & $0 \mathrm{~g}_{\mathrm{B}}$ & $4{ }^{\mathrm{e}} \mathrm{A}$ & $0 \mathrm{f}_{\mathrm{B}}$ \\
\hline & & Fusarium graminearum Schwabe & $18^{\mathrm{b}} \mathrm{A}$ & $12 \mathrm{~d}_{B}$ & $18^{\mathrm{b}} \mathrm{A}$ & $2^{\mathrm{f}} \mathrm{E}$ & $2{ }^{f} \mathrm{E}$ & $6^{\mathrm{d}} \mathrm{D}$ & $10{ }^{\mathrm{e}} \mathrm{C}$ \\
\hline & & Fusarium oxysporum Schltdl. & ${ }^{0} \mathrm{~g}_{\mathrm{C}}$ & $0^{\mathrm{h}} \mathrm{C}$ & $0 \mathrm{e}_{\mathrm{C}}$ & $2{ }^{f}{ }_{B}$ & $4{ }^{\mathrm{e}} \mathrm{A}$ & $0^{\mathrm{f}} \mathrm{C}$ & $0{ }^{\mathrm{f}} \mathrm{C}$ \\
\hline & & Penicillium chrysogenum Thom & $0 g_{B}$ & $2^{\mathrm{h}} \mathrm{A}$ & $0 \mathrm{e}_{\mathrm{B}}$ & $0 g_{B}$ & $0 \mathrm{~g}_{\mathrm{B}}$ & $0{ }^{\mathrm{f}} \mathrm{B}$ & $0{ }_{B}^{f}$ \\
\hline & & Rhizopus stolonifer (Ehrenb.) Vuill. & $3{ }^{\text {ef }} \mathrm{C}$ & $8 \mathrm{e}_{\mathrm{B}}$ & $0^{\mathrm{e}} \mathrm{D}$ & $4{ }^{\mathrm{e}} \mathrm{C}$ & $14^{\mathrm{d}} \mathrm{A}$ & $0{ }^{\mathrm{f}} \mathrm{D}$ & $0{ }^{\mathrm{f}} \mathrm{D}$ \\
\hline
\end{tabular}


Table A3. Cont.

\begin{tabular}{|c|c|c|c|c|c|c|c|c|c|}
\hline & & \multirow{2}{*}{ Fungi Species } & \multicolumn{7}{|c|}{ Treatment } \\
\hline & & & Control & HT & Z-1-0 & Z-0-1 & Z-1-1 & Z-2-1 & Z-2-2 \\
\hline \multirow{4}{*}{ Pea } & disinfected & $\begin{array}{c}\text { Alternaria alternata (Fr.) Keissl. } \\
\text { Botrytis cinerea Pers. } \\
\text { Cladosporium cladosporioides (Fresen.) G.A. de Vries } \\
\text { Cladosporium herbarum (Pers.) Link } \\
\text { Fusarium avenaceum (Fr.) Sacc. } \\
\text { Fusarium culmorum (W.G. Sm.) Sacc. } \\
\text { Fusarium equiseti (Corda) Sacc. } \\
\text { Fusarium graminearum Schwabe } \\
\text { Fusarium oxysporum Schltdl. } \\
\text { Rhizopus stolonifer (Ehrenb.) Vuill. }\end{array}$ & $\begin{array}{l}20{ }^{\mathrm{a}} \mathrm{BC} \\
0{ }^{\mathrm{f}} \mathrm{D} \\
0{ }^{\mathrm{f}} \mathrm{B} \\
0{ }^{\mathrm{f}} \mathrm{B} \\
0{ }^{\mathrm{f}} \mathrm{C} \\
12^{\mathrm{c}} \mathrm{C} \\
4{ }^{\mathrm{e}} \mathrm{DE} \\
16^{\mathrm{b}} \mathrm{A} \\
0{ }^{\mathrm{f}} \mathrm{B} \\
10^{\mathrm{d}}{ }_{\mathrm{A}}\end{array}$ & $\begin{array}{l}20^{\mathrm{b}} \mathrm{BC} \\
2{ }^{\mathrm{cd}}{ }_{C} \\
2{ }^{\mathrm{cd}}{ }_{\mathrm{A}} \\
0{ }^{\mathrm{e}} \\
0^{\mathrm{e}}{ }_{\mathrm{C}} \\
24^{\mathrm{a}}{ }_{\mathrm{B}} \\
3^{\mathrm{c}} \mathrm{E} \\
3^{\mathrm{c}}{ }_{\mathrm{C}}^{\mathrm{C}} \\
1{ }^{\mathrm{de}_{\mathrm{AB}}} \\
2{ }^{\mathrm{cd}}{ }_{\mathrm{E}}\end{array}$ & $\begin{array}{l}22^{\mathrm{b}} \mathrm{B} \\
0^{\mathrm{f}} \mathrm{D} \\
0 \mathrm{f}^{\mathrm{f}} \\
2{ }^{\mathrm{e}} \mathrm{B} \\
0^{\mathrm{f}} \mathrm{C} \\
32^{\mathrm{a}}{ }^{\mathrm{A}} \\
6^{\mathrm{c}}{ }_{\mathrm{CD}} \\
6^{\mathrm{C}}{ }^{\mathrm{C}} \\
0{ }^{\mathrm{f}} \mathrm{B} \\
4{ }^{\mathrm{d}} \mathrm{D}\end{array}$ & $\begin{array}{l}16^{\mathrm{b}} \mathrm{CD} \\
4{ }^{\mathrm{de}}{ }_{\mathrm{B}} \\
2{ }^{\mathrm{ef}} \mathrm{A} \\
0{ }_{\mathrm{f}}^{\mathrm{A}} \\
2^{\mathrm{ef}}{ }_{\mathrm{A}} \\
32^{\mathrm{a}} \mathrm{A} \\
12{ }^{\mathrm{c}} \mathrm{A} \\
6{ }^{\mathrm{d}} \mathrm{B} \\
0{ }^{\mathrm{f}} \mathrm{B} \\
6{ }^{\mathrm{d}} \mathrm{C}\end{array}$ & $\begin{array}{l}8{ }^{\mathrm{c}} \mathrm{E} \\
8^{\mathrm{c}} \mathrm{A} \\
0^{\mathrm{f}}{ }_{\mathrm{B}} \\
0^{\mathrm{f}}{ }_{\mathrm{B}} \\
0^{\mathrm{f}} \mathrm{C} \\
25^{\mathrm{a}}{ }_{\mathrm{B}} \\
10^{\mathrm{b}}{ }_{\mathrm{AB}} \\
4{ }^{\mathrm{d}}{ }_{\mathrm{BC}} \\
2^{\mathrm{e}_{\mathrm{A}}} \\
4^{\mathrm{d}} \\
\end{array}$ & $\begin{array}{l}30^{\mathrm{b}}{ }_{\mathrm{A}} \\
0^{\mathrm{d}}{ }_{\mathrm{D}} \\
0^{\mathrm{d}_{\mathrm{B}}} \\
0^{\mathrm{d}_{\mathrm{B}}} \\
0^{\mathrm{d}_{\mathrm{C}}} \\
34^{\mathrm{a}}{ }_{\mathrm{A}} \\
8^{\mathrm{c}_{\mathrm{BC}}} \\
0^{\mathrm{d}_{\mathrm{D}}} \\
0^{\mathrm{d}_{\mathrm{B}}} \\
0^{\mathrm{d}_{\mathrm{F}}}\end{array}$ & $\begin{array}{l}14^{\mathrm{a}} \mathrm{D} \\
4{ }^{\mathrm{d}}{ }_{\mathrm{B}} \\
0{ }^{\mathrm{e}}{ }_{\mathrm{B}} \\
4^{\mathrm{d}}{ }_{\mathrm{A}} \\
1^{\mathrm{e}_{\mathrm{B}}} \\
12^{\mathrm{ab}} \mathrm{C} \\
10^{\mathrm{bc}}{ }^{\mathrm{CB}} \\
4^{\mathrm{d}}{ }_{\mathrm{BC}} \\
1^{\mathrm{e}}{ }_{\mathrm{AB}} \\
8^{\mathrm{c}}{ }_{\mathrm{B}}\end{array}$ \\
\hline & & $\begin{array}{c}\text { Alternaria alternata (Fr.) Keissl. } \\
\text { Aspergillus niger Tiegh. } \\
\text { Botrytis cinerea Pers. } \\
\text { Cladosporium cladosporioides (Fresen.) G.A. de Vries }\end{array}$ & $\begin{array}{l}39^{\mathrm{a}} \mathrm{F} \\
0 \mathrm{~g}_{\mathrm{B}} \\
7^{\mathrm{de}} \mathrm{A} \\
2^{\mathrm{efg}}{ }_{\mathrm{C}}\end{array}$ & $\begin{array}{l}54{ }^{\mathrm{a}} \mathrm{D} \\
0{ }^{\mathrm{f}} \mathrm{B} \\
0{ }^{\mathrm{f}} \mathrm{C} \\
0{ }^{\mathrm{f}} \mathrm{D}\end{array}$ & $\begin{array}{l}80^{\mathrm{a}}{ }_{\mathrm{B}} \\
0^{\mathrm{d}}{ }_{\mathrm{B}} \\
0^{\mathrm{d}_{\mathrm{C}}} \\
0^{\mathrm{d}_{\mathrm{D}}}\end{array}$ & $\begin{array}{l}44^{\mathrm{a}} \mathrm{E} \\
2{ }^{\mathrm{de}}{ }_{\mathrm{A}} \\
1 \mathrm{de}_{\mathrm{BC}} \\
8^{\mathrm{c}}{ }_{\mathrm{A}}^{\mathrm{A}}\end{array}$ & $\begin{array}{l}74^{\mathrm{a}} \mathrm{C} \\
0^{\mathrm{d}_{\mathrm{B}}} \\
0^{\mathrm{d}}{ }_{\mathrm{C}} \\
4^{\mathrm{d}_{\mathrm{B}}}\end{array}$ & $\begin{array}{l}86^{\mathrm{a}} \mathrm{A} \\
0^{\mathrm{d}}{ }_{\mathrm{B}} \\
2 \mathrm{~d}_{\mathrm{B}}^{\mathrm{d}} \\
0^{\mathrm{d}_{\mathrm{D}}}\end{array}$ & $\begin{array}{l}52{ }^{\mathrm{a}} \mathrm{D} \\
0{ }^{\mathrm{e}}{ }_{\mathrm{B}} \\
0{ }^{\mathrm{e}}{ }_{\mathrm{C}} \\
8^{\mathrm{c}}{ }_{\mathrm{A}}\end{array}$ \\
\hline & & Cladosporium herbarum (Pers.) Link & $26^{\mathrm{b}} \mathrm{DE}$ & $9^{\mathrm{c}} \mathrm{E}$ & $58^{\mathrm{b}} \mathrm{A}$ & $30^{\mathrm{b}} \mathrm{CD}$ & $\mathrm{b}_{\mathrm{ABC}}^{46}$ & $\begin{array}{c}34 \\
b_{B C D}^{34}\end{array}$ & $52^{\mathrm{a}} \mathrm{AB}$ \\
\hline & non-disinfected & $\begin{array}{c}\text { Epicoccum nigrum Link } \\
\text { Fusarium avenaceum (Fr.) Sacc. } \\
\text { Fusarium culmorum (W.G. Sm.) Sacc. } \\
\text { Fusarium equiseti (Corda) Sacc. } \\
\text { Fusarium graminearum Schwabe } \\
\text { Fusarium oxysporum Schltdl. } \\
\text { Rhizopus stolonifer (Ehrenb.) Vuill. } \\
\text { Sclerotinia sclerotiorum (Lib.) de Bary } \\
\text { Trichoderma harzianum Rifai }\end{array}$ & $\begin{array}{l}3{ }^{\operatorname{defg}_{B}} \\
1^{\mathrm{fg}_{\mathrm{C}}} \\
15^{\mathrm{c}}{ }_{\mathrm{B}} \\
8^{\mathrm{d}}{ }_{\mathrm{A}} \\
6^{\mathrm{def}_{\mathrm{A}}} \\
0^{\mathrm{g}_{\mathrm{C}}} \\
1^{\mathrm{fg}_{\mathrm{C}}} \\
1^{\mathrm{fg}}{ }_{\mathrm{C}} \\
0{ }^{{ }_{\mathrm{B}}}\end{array}$ & $\begin{array}{l}3{ }^{\mathrm{de}} \mathrm{B}_{\mathrm{B}} \\
0{ }^{\mathrm{f}} \mathrm{D} \\
22{ }^{\mathrm{b}} \mathrm{A} \\
0{ }^{\mathrm{f}} \mathrm{E} \\
0{ }^{\mathrm{f}} \mathrm{C} \\
4{ }^{\mathrm{d}} \mathrm{A} \\
8{ }^{\mathrm{c}} \\
0{ }^{\mathrm{f}} \\
2{ }^{\mathrm{e}} \\
{ }_{\mathrm{C}}^{\mathrm{A}}\end{array}$ & $\begin{array}{l}7^{\mathrm{c}} \mathrm{A} \\
0^{\mathrm{d}_{\mathrm{D}}} \\
4^{\mathrm{cd}}{ }_{\mathrm{E}} \\
4^{\mathrm{cd}}{ }_{\mathrm{C}} \\
0^{\mathrm{d}_{\mathrm{C}}} \\
0^{\mathrm{d}_{\mathrm{C}}} \\
0^{\mathrm{d}_{\mathrm{D}}} \\
4^{\mathrm{cd}}{ }_{\mathrm{B}} \\
0^{\mathrm{d}_{\mathrm{B}}}\end{array}$ & 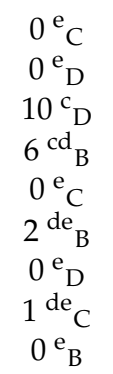 & $\begin{array}{l}0^{d_{C}} \\
2 d_{B} \\
10^{c}{ }_{D} \\
2{ }^{d}{ }_{D} \\
0{ }^{d_{C}} \\
0{ }^{d_{C}} \\
0^{d_{D}} \\
0^{d_{C}} \\
0^{d_{B}}\end{array}$ & $\begin{array}{c}33^{d_{B}} \\
4{ }^{d_{A}} \\
12^{{ }^{c}}{ }_{C D} \\
4 d_{C}^{d_{C}} \\
2 d^{d_{B}} \\
0{ }^{d_{C}} \\
4 d_{B} \\
0^{d_{C}} \\
0^{d_{B}}\end{array}$ & $\begin{array}{c}0^{\mathrm{e}}{ }_{\mathrm{C}} \\
0^{\mathrm{e}}{ }_{\mathrm{D}} \\
14^{\mathrm{b}}{ }^{\mathrm{BC}} \\
4^{\mathrm{cde}}{ }_{\mathrm{C}} \\
0^{\mathrm{e}}{ }_{\mathrm{C}} \\
2^{\mathrm{de}} \mathrm{e}_{\mathrm{B}} \\
0^{\mathrm{e}}{ }_{\mathrm{D}} \\
6^{\mathrm{cd}}{ }_{\mathrm{A}} \\
0^{\mathrm{e}}{ }_{\mathrm{B}}^{\mathrm{B}}\end{array}$ \\
\hline
\end{tabular}

${ }^{1}$ For each treatment, means followed by the same letter are not statistically different at $\alpha \leq 0.05$ according to Tukey's HSD test. Small letters mark treatment differences between within a given year; they refer to column means. Capital letters mark the effect of years within a given treatment; they refer to row means. 


\section{References}

1. Ecobichon, D.J. Our changing perspectives on benefit and risks of pesticides: A historical overview. Neurotoxicology 2000, 21, 211-218. [PubMed]

2. Lejman, A.; Ogórek, R.; Sobkowicz, P. The effect of mechanical weed control in barley-pea mixture on colonization of barley grain by fungi. Part 1. Pol. J. Environ. Stud. 2015, 24, 141-149. [CrossRef]

3. Lejman, A.; Ogórek, R.; Sobkowicz, P. The effect of mechanical weed control in barley-pea mixture on colonization of pea seeds by fungi. Part 2. Pol. J. Environ. Stud. 2015, 26, 2485-2492. [CrossRef]

4. Aktar, W.M.; Sengupta, D.; Chowdhury, A. Impact of pesticides use in agriculture: Their benefits and hazards. Interdiscip. Toxicol. 2009, 2, 1-12. [CrossRef] [PubMed]

5. WHO. Geneva: World Health Organization, Public Health Impact of Pesticides Used in Agriculture; WHO/UNEP Working Group: Geneva, Switzerland, 1990; p. 88.

6. Environews Forum. Killer environment. EHP 1999, 107, A62. [CrossRef]

7. Bradbery, S.M.; Watt, B.E.; Proudfoot, A.T.; Vale, J.A. Mechanisms of toxicity, clinical features, and management of acute chlorophenoxy herbicide poisoning: a review. Clin. Toxicol. 2000, 38, 111-122. [CrossRef]

8. Wally, O.; Punaj, Z.K. Genetic engineering for increasing fungal and bacterial disease resistance in crop plants. GM crops 2010, 1, 199-206. [CrossRef] [PubMed]

9. Bakhsh, A.; Khabbazi, S.D.; Baloch, F.S.; Demirel, U.; Çalişkan, M.E.; Hatipoğlu, R.; Özcan, S.; Özkan, H. Insect-resistant transgenic crops: Eetrospect and challenges. Turk. J. Aric. For. 2015, 39, 531-548. [CrossRef]

10. Denner, F.D.N.; Millard, C.P.; Wehner, F.C. Effect of soil solarisation and mouldboard ploughing black dot of potato, caused by Colletotrichum coccodes. Potato Res. 2000, 43, 195-201. [CrossRef]

11. Malézieux, E.; Crozat, Y.; Dupraz, C.; Laurans, M.; Makowski, D.; Ozier-Lafontaine, H.; Rapidel1, B.; de Tourdonnet, S.; Valantin-Morison, M. Mixing plant species in cropping systems: Concepts, tools and models. A review. Agron. Sustain. 2009, 29, 43-62. [CrossRef]

12. Paulsen, H.M.; Schochow, M.; Ulber, B.; Kühne, S.; Rahmann, G. Mixed cropping systems for biological control of weeds and pests in organic oilseed crops. Asp. Appl. Biol. 2006, 79, 215-220.

13. Sobkowicz, P. Competition between triticale and field beans in additive intercrops. Plant Soil Environ. 2006, 52, 47-56. [CrossRef]

14. Kang, Z.; Buchenauer, H.; Huang, L.; Han, Q.; Zhang, C.H. Cytological and immunocytochemical studies on responses of wheat spikes of the resistant Chinese cv. Sumai 3 and the susceptible cv. Xiaoyan 22 to infection by Fusarium graminearum. Eur. J. Plant Pathol. 2008, 120, 383-396. [CrossRef]

15. Pasanen, A.L.; Rautiala, S.; Kasanen, J.P.; Raunio, P.; Rantamäki, J.; Kalliokoski, P. The relationship between measured moisture conditions and fungal concentrations in water-damaged building materials. Indoor Air 2000, 10, 111-120. [CrossRef] [PubMed]

16. Rasmussen, J.; Svenningsen, T. Selective weed harrowing in cereals. Biol. Agric. Hortic. 1995, 12, $29-46$. [CrossRef]

17. Malschi, D.; Ivaş, A.D.; Valean, A.M.; Cheţan, F.; Tritean, N.; Cheţan, C.; Pataki, I. Current Importance of wheat pests in the cultural technologies of soil no-tillage conservative system and of antierosional agroforestry curtains system, in Transylvania. ProEnviron. Promediu 2015, 8, 159-169.

18. Rasmussen, J.; Ascard, J. Weed Control in Organic Farming Systems; Department for Environment, Food and Rural Affairs: Lundon, UK, 1995; pp. 49-67.

19. Kurstjens, D.A.G.; Perdock, U.D.; Goense, D. Selective uprooting by weed harrowing on sandy soils. Weed Res. 2000, 40, 431-447. [CrossRef]

20. Rasmussen, I.A. The effect of sowing date, stale seedbed row width and mechanical weed control on weeds and yields of organic winter wheat. Weed Res. 2004, 44, 12-20. [CrossRef]

21. Rasmussen, J.; Kurtzmann, J.I.; Jensen, A. Tolerance of competitive spring barley cultivars to weed harrowing. Weed Res. 2004, 44, 446-452. [CrossRef]

22. Lejman, A. Weed Control in Mixture of Spring Barley and Field Pea. Ph.D. Thesis, Wrocław University of Environmental and Life Sciences, Wrocław, Poland, 2015.

23. Wnuk, A.; Górny, A.G.; Bocianowski, J.; Kozak, M. Visualizing harvest index in crops. CBCS 2013, 8, 48-59.

24. Dugan, F.M. The Identification of Fungi: An Illustrated Introduction with Keys, Glossary, and Guide to Literature; Amer Phytopathological Society: St. Paul, MN, USA, 2006. 
25. Simmons, E.G. Alternaria: An identification manual; CBS Fungal Biodiversity Centre: Utrecht, The Netherlands, 2008.

26. Watanabe, T. Pictorial Atlas of Soil and Seed Fungi: Morphologies of Cultured Fungi and Key to Species, 3rd ed.; CRC Press: London, UK, 2010.

27. Bliss, C.T. The method of probits. Science 1934, 79, 38-39. [CrossRef] [PubMed]

28. Cerkauskas, R.F.; Dhingra, D.; Sinclair, J.B.; Asmus, G. Amaranthus spinosus, Leonotis nepetaefolia, and Leonurus sibiricus: New hosts of Phomopsis spp. in Brazil. Plant Dis. 1983, 67, 821-824. [CrossRef]

29. Helbig, J.B.; Carroll, R.B. Dicotyledonous weeds as a source of Fusarium oxysporum pathogenic on soybean. Plant Dis. 1984, 68, 694-696. [CrossRef]

30. Baturo, A. Effect of biopreparations on the health of grain of spring barley (Hordeum vulgare) in organic system. Phytopatholog 2009, 53, 19-30.

31. Gleń, K.; Boligłowa, E.; Gospodarek, J. Fungi colonizing broad bean seeds depending on protection method. Pol. J. Agron. 2013, 12, 9-16.

32. Woudenberg, J.H.; Groenewald, J.Z.; Binder, M.; Crous, P.W. Alternaria redefined. Stud. Mycol. 2013, 75, 171-212. [CrossRef] [PubMed]

33. D'Amato, G.; Spieksma, F.T.M. Aerobiologic and clinical aspects of mould allergy in Europe. Allergy 1995, 50, 870-877. [CrossRef] [PubMed]

34. Zare, L. The casual agent of barley black point disease in certified seed loads in Iran. IJACS 2013, 5, 332-335.

35. Rademacher, B. Mechanische Unkrautbekämpfung im Getreide. Landtechnik 1962, 17, 194-198.

36. Velykis, A.; Maiksteniene, S.; Arlauskiene, A.; Kristaponyte, I.; Satkus, A. Mechanical weed control in organically grown spring oat and field pea crops. Agron. Res. 2009, 7, 542-547.

37. Padro, G.; Cirujeda, A.; Aibar, J.; Cavero, J.; Zaragoza, C. Weed harrowing in winter cereal under semi-arid conditions. Span. J. Agric. Res. 2008, 6, 661-670.

(C) 2019 by the authors. Licensee MDPI, Basel, Switzerland. This article is an open access article distributed under the terms and conditions of the Creative Commons Attribution (CC BY) license (http:/ / creativecommons.org/licenses/by/4.0/). 